\title{
Mitigating the Effects of Sea-Level Rise on Estuaries of the Mississippi Delta Plain Using River Diversions
}

\author{
Eric D. White 1,2,*(D), Ehab Meselhe ${ }^{2}$, Denise Reed ${ }^{3}\left(\mathbb{D}\right.$, Alisha Renfro ${ }^{4}$, \\ Natalie Peyronnin Snider ${ }^{5}$ and Yushi Wang ${ }^{6}$ \\ 1 Planning \& Research Division, Louisiana Coastal Protection and Restoration Authority, 150 Terrace Avenue, \\ Baton Rouge, LA 70802, USA \\ 2 Department of River-Coastal Science and Engineering, Tulane University, 627 Lindy Boggs Center, \\ 6823 St. Charles Ave., New Orleans, LA 70118, USA; emeselhe@tulane.edu \\ 3 Pontchartrain Institute for Environmental Sciences, University of New Orleans, 2000 Lakeshore Drive, \\ New Orleans, LA 70148, USA; djreed@uno.edu \\ 4 National Wildlife Federation, 3801 Canal Street, Suite 32, New Orleans, LA 70119, USA; renfroa@nwf.org \\ 5 Environmental Defense Fund, 1875 Connecticut Avenue NW, Suite 600, Washington, DC 20009, USA; \\ nsnider@edf.org \\ 6 The Water Institute of the Gulf, 1110 River Road S., Suite 200, Baton Rouge, LA 70802, USA; \\ ywang@thewaterinstitute.org \\ * Correspondence: eric.white@la.gov; Tel.: +1-225-342-1286
}

Received: 7 August 2019; Accepted: 23 September 2019; Published: 28 September 2019

check for updates

\begin{abstract}
Using the Mississippi River as a tool for restoration has been a key element of restoration planning in Louisiana for decades. The results of allowing river water and sediment back into the coastal system are manifested in a number of places in present day Louisiana, with additional plans for large scale sediment and water diversions from the Mississippi River. Many previous numerical modeling studies have focused on sediment delivery to Louisiana estuaries. This study examines the effects of river diversions on salinity gradients in receiving estuarine basins. The Integrated Compartment Model, a planning-level model that simulates multi-decadal change in estuarine hydrodynamics and wetland systems under assumed sea-level rise scenarios, was used to assess the estuarine salinity gradient under potential management regimes. The simulations for current conditions are compared to a future 50-year simulation with additional diversions, as well as cases with a variety of diversion options. This modeling analysis shows that without additional action, 50-years of sea-level rise could result in substantial increases in salinity throughout the Mississippi Delta Plain estuaries. This can be largely offset with additional large river diversions which can maintain variable salinity gradients throughout the estuary basins.
\end{abstract}

Keywords: Mississippi River Delta; Louisiana; salinity; sediment; wetland loss; estuary; diversion; sea-level rise; environmental planning; coastal restoration

\section{Introduction}

The impacts from projected future sea-level rise are expected to be extensive for the World's River Deltas, with the loss of land and habitat diversity threatening the inhabitants, resources and ecology of these low-lying coastal areas [1,2]. Many deltas have already experienced broad change, resulting in a loss of habitat extent and diversity due to human activities [3]. The Mississippi River Delta is a river-dominated delta that was built in a series of successive lobes over the last 7500 years [4]. However, over the past 80 years, Louisiana has lost $3800 \mathrm{~km}^{2}$ of land on the Mississippi River's deltaic coastal plain [5] due to a variety of human-induced and natural factors, such as rising sea levels, levee construction along the Mississippi River, sediment compaction due to pressure 
from overlying sediments and organic decomposition, fluid withdrawal, decreased fluvial sediment discharge, hurricanes, and widespread hydrologic alteration [6,7].

Over time, the interaction between the Mississippi River and the delta plain has been progressively managed $[8,9]$ such that there are presently a few uncontrolled connections upstream of the Birdsfoot Delta [10]. Reconnecting the river with the delta plain is now widely recognized as an essential tool in the future sustainability of the wetland-dominated coastal ecosystem [11-14], and this approach has been central to restoration planning in Louisiana for decades [15]. Two freshwater diversions, Caernarvon and Davis Pond (Table 1) were built in the late 20th century specifically for the management of the estuarine gradient to support conditions for fisheries in the receiving basins. Future managed reconnections are usually in the form of sediment diversions. These are structures with gates built in the existing river levee system that would be operated to allow river water, sediment and nutrients to flow into the wetlands adjacent to the river to build new land and sustain existing wetlands. The results of allowing river water and sediment back into the coastal system are manifest in a number of places including the delta of the Wax Lake Outlet, mining of accumulated sediment in the Bonnet Carre Spillway, crevasse splays in the Birdsfoot Delta and revitalized marshes adjacent to freshwater diversions and siphons [14]. At the same time, adjustments in the estuarine gradient as freshwater is introduced are expected to have some effect on the habitat for important commercial fisheries, including oysters [16], brown shrimp [17,18], and other commercial species [19].

Table 1. Locations of existing or planned connections between the Mississippi River and estuarine basins. Barataria (BA), Breton (BR) and Pontchartrain (PO) identify the receiving basin. ID tracks the locations on Figure 1.

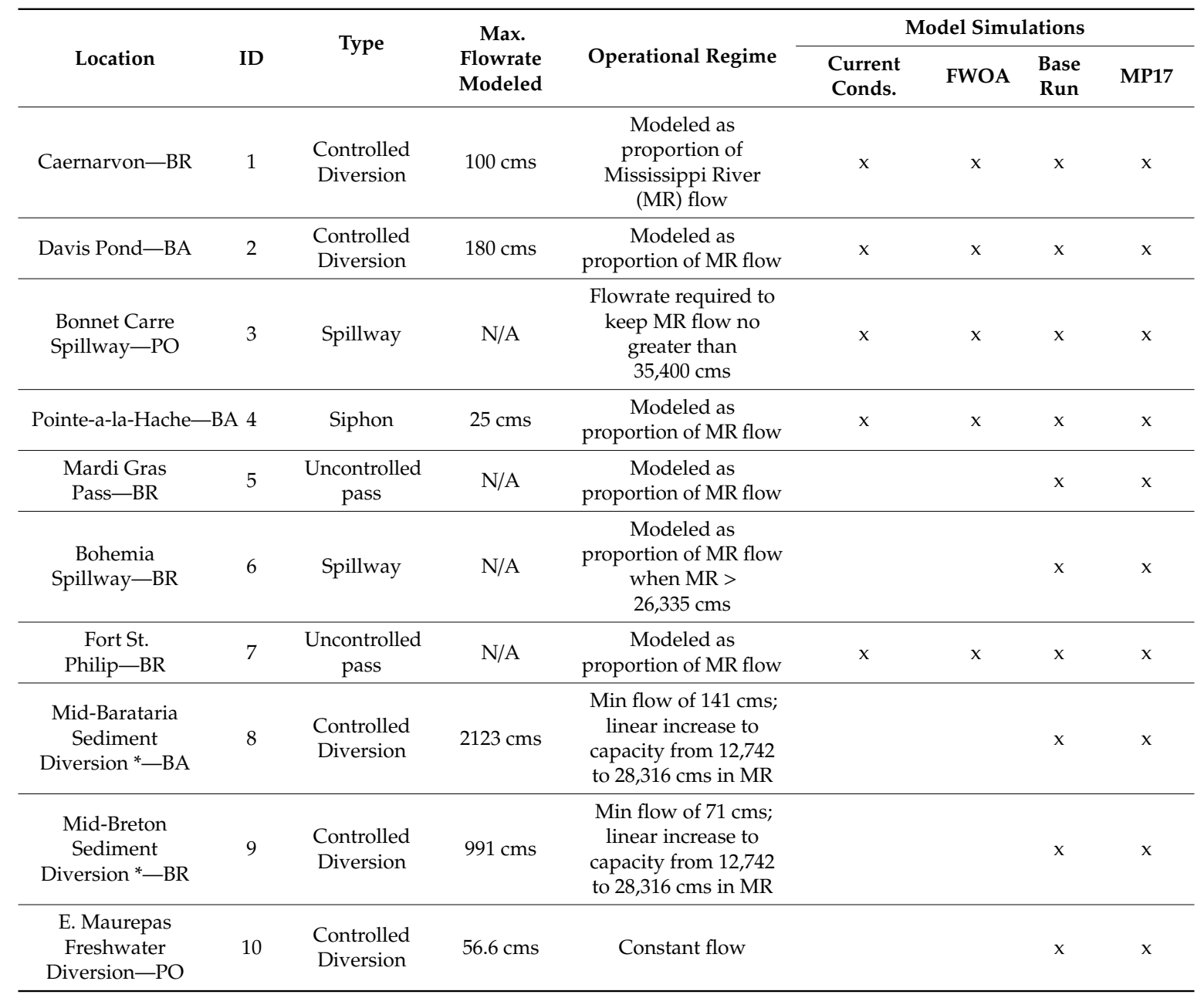


Table 1. Cont.

\begin{tabular}{|c|c|c|c|c|c|c|c|c|}
\hline \multirow[b]{2}{*}{ Location } & \multirow[b]{2}{*}{ ID } & \multirow[b]{2}{*}{ Type } & \multirow{2}{*}{$\begin{array}{l}\text { Max. } \\
\text { Flowrate } \\
\text { Modeled }\end{array}$} & \multirow[b]{2}{*}{ Operational Regime } & \multicolumn{4}{|c|}{ Model Simulations } \\
\hline & & & & & $\begin{array}{l}\text { Current } \\
\text { Conds. }\end{array}$ & FWOA & $\begin{array}{l}\text { Base } \\
\text { Run }\end{array}$ & MP17 \\
\hline $\begin{array}{l}\text { Bayou Lafourche } \\
\text { Diversion-BA }\end{array}$ & 11 & $\begin{array}{l}\text { Controlled } \\
\text { Diversion }\end{array}$ & $28 \mathrm{cms}$ & Constant flow & & & & $x$ \\
\hline $\begin{array}{c}\text { Lower Breton } \\
\text { Diversion-BR }\end{array}$ & 12 & $\begin{array}{l}\text { Controlled } \\
\text { Diversion }\end{array}$ & $1415 \mathrm{cms}$ & $\begin{array}{c}\text { Closed below } \\
5663 \mathrm{cms} \text { in MR; linear } \\
\text { increase to } 1415 \text { at } \\
28,316 \mathrm{cms} \text { in MR; } \\
\text { variable above } \\
28,316 \mathrm{cms} \mathrm{MR}\end{array}$ & & & & $x$ \\
\hline $\begin{array}{l}\text { Central Wetlands } \\
\text { Diversion-PO }\end{array}$ & 13 & $\begin{array}{l}\text { Controlled } \\
\text { Diversion }\end{array}$ & $141 \mathrm{cms}$ & Constant flow & & & & $x$ \\
\hline $\begin{array}{l}\text { Union Freshwater } \\
\text { Diversion-PO }\end{array}$ & 14 & $\begin{array}{l}\text { Controlled } \\
\text { Diversion }\end{array}$ & $708 \mathrm{cms}$ & $\begin{array}{c}\text { Closed below } \\
5663 \mathrm{cms} \text { or above } \\
16,990 \text { in MR; } 708 \mathrm{cms} \\
\text { for MR at } 11,326 \mathrm{cms} \text {; } \\
\text { linear from } 0 \text { to } \\
708 \mathrm{cms} \text { from } \\
5663 \mathrm{cms} \text { to } \\
11,326 \mathrm{cms} \text { in MR and } \\
\text { held constant between } \\
11,326 \mathrm{cms} \text { and } \\
16,990 \mathrm{cms} \text { in MR. }\end{array}$ & & & & $\mathrm{x}$ \\
\hline $\begin{array}{c}\text { Ama } \\
\text { Diversion-BA }\end{array}$ & 15 & $\begin{array}{l}\text { Controlled } \\
\text { diversion }\end{array}$ & $1415 \mathrm{cms}$ & $\begin{array}{c}\text { Closed below } \\
5663 \mathrm{cms} \text { in MR; linear } \\
\text { increase to } 1415 \text { at } \\
28,316 \mathrm{cms} \text { in MR; } \\
\text { variable above } \\
28,316 \mathrm{cms} \mathrm{MR}\end{array}$ & & & & $x$ \\
\hline Ostrica-BR & 16 & $\begin{array}{l}\text { Uncontrolled } \\
\text { pass }\end{array}$ & $\mathrm{N} / \mathrm{A}$ & $\begin{array}{c}\text { Modeled as } \\
\text { proportion of MR flow } \\
\text { when } \mathrm{MR}>22,653\end{array}$ & $\mathrm{x}$ & $\mathrm{x}$ & $\mathrm{x}$ & $\mathrm{x}$ \\
\hline
\end{tabular}

Louisiana has a long history of coastal restoration and protection planning. In response to the past and the growing threat of future coastal land loss due to rising sea levels, subsidence, and altered hydrology, Louisiana has developed a coastwide plan for coastal restoration and storm surge-based risk reduction over the next 50 years. The implementation of this plan would reduce land loss and expected annual damages, compared to a future with no action [20-22]. Through the 2017 Coastal Master Plan process, the restoration projects were analyzed and selected based on their ability to build or sustain land against a potential future landscape that incorporated up to $0.8 \mathrm{~m}$ of eustatic sea-level rise over the next 50 years. With the effort and investment envisaged in the 2017 plan, nearly $3000 \mathrm{~km}^{2}$ of land is projected to be built or sustained that may have otherwise been lost. The expected annual damages from storm surge-based flooding are projected to be reduced by $\$ 12.2$ billion at year 50 [22]. The 2017 plan selected a variety of restoration project types including river sediment diversions.

A number of sediment diversions from the Mississippi River have been identified to support land building and wetland sustainability [21,22]. The focus on sediment recognizes the value of that resource. Freshwater diversions of various scales have been used for decades in Louisiana to manage estuarine salinity gradients. The 2017 Coastal Master Plan also introduced the concept of using diversions at strategic and suitable locations that operate only under low-moderate river discharges to provide supplemental freshwater to estuarine wetlands, especially freshwater wetlands, during the times of the year when salinities often increase. The ecosystem diversity can be important outcomes of strategically placed riverine diversions, as well as land-building and land maintenance.

Moving water and sediment from the river into the estuarine basins results in ecosystem change relative to current or past conditions. However, the forward-looking analysis that considers future change, especially that associated with sea-level rise is needed. 
The analysis described here explores how the use of river freshwater and sediment resources at multiple locations, individually or in combinations, year-round or seasonally, and in different magnitudes can be used to sustain the coastal ecosystem. It uses numerical experiments to consider several strategies for diversion operation and shows how the effects of diversion vary over time as the sea-level rises, between the years as the river fluctuates, and among estuarine basins with different landscape settings.

\section{Methods}

This analysis utilizes tools developed for the 2017 Coastal Master Plan to further explore the potential of the Mississippi River as a tool to support the sustainability of the Mississippi Delta Plain and the economic activities that depend on it. The Integrated Compartment Model (ICM) is a planning-level model that was developed by integrating into a single modeling platform several models that had previously been used for coastal zone planning and research in Louisiana [23]. The models that are included as subroutines within the ICM framework include a hydrologic and hydraulic model [24], a vegetation dynamics model [25], a wetland morphology/elevation change model [26], as well a barrier island morphology model and several receptor models that summarize the hydrologic and landscape conditions into numerous habitat indices and decision-making metrics. The hydraulic and hydrologic model, ICM-Hydro, simulates on a sub-daily timestep: water level (stage), flow rate, salinity, water temperature, suspended sediment concentration, sediment deposition and resuspension within open water areas, sediment deposition on the marsh surface, and a variety of water quality/nutrient constituents. The seasonal hydrologic conditions and salinity are then utilized by the vegetation dynamics model, ICM-LAVegMod, to predict the relative likelihood of wetland vegetation species being present under such conditions. The patterns of inundation, salinity penetration, sediment deposition and organic matter accretion are all taken into account within the wetland morphology/elevation change model, ICM-Morph, to predict whether wetland areas remain as viable emergent vegetation or collapse into open water due to either persistent inundation stress or acute salinity stress. Finally, as the coastal wetlands change in vegetative cover, and the resultant changes in elevation and land/water composition, the hydraulic network of the estuary is updated prior to the next model year in ICM-Hydro, to simulate the changing hydraulic and hydrologic conditions that occur as a result of collapsing wetland areas.

Prior to any modeling analysis, the ICM was calibrated using observational data from 2010 to 2013, and then validated on observations from 2006 to 2009. These time periods correspond to the development and widespread availability of data from the Coastwide Reference Monitoring System (CRMS), which collects hourly water level and salinity data across coastal Louisiana [27]. The water level predictions were calibrated with a goal that $80 \%$ of compartments should have a prediction bias of less than $0.15 \mathrm{~m}$ in the daily mean water level prediction. The magnitude of this bias corresponds approximately to the error in the underlying topographic digital elevation model (DEM) used in this analysis, which varies from a RMSE of 0.07 to $0.3 \mathrm{~m}$ [28]. The hydraulic link capacity and bed roughness were adjusted if the observed stage signal and amplitude were not in satisfactory agreement with the model. Due to the apparent datum inconsistencies in certain observed stations (as well as clear patterns of hydraulic controls influencing observed water levels), certain observed data were excluded when assessing the overall model fit. These inconsistent datasets were still used to visually compare modeled and observed hydrographs, but they were excluded from any aggregate model performance statistics.

Salinity calibration was also conducted for the same 2010 through 2013, time frame. The model agreement was defined as $80 \%$ of the compartments with a bias in salinity prediction of less than 1 ppt. Coastwide, $76 \%$ of the model-observation pairs met this goal. In the Mississippi River Delta (Pontchartrain, Breton and Barataria basins, Figure 1), 87\% of the model-observation pairs met the bias target of 1 ppt or less (refer to Tables S2 and S3 and Figures S2-S5 in Supplementary Material). To attain this, a model parameter representing a combined dispersion diffusion coefficient, $\mathrm{E}_{\mathrm{xy}}$, was adjusted if the observed salinity signal and amplitude were not matched by the model. 


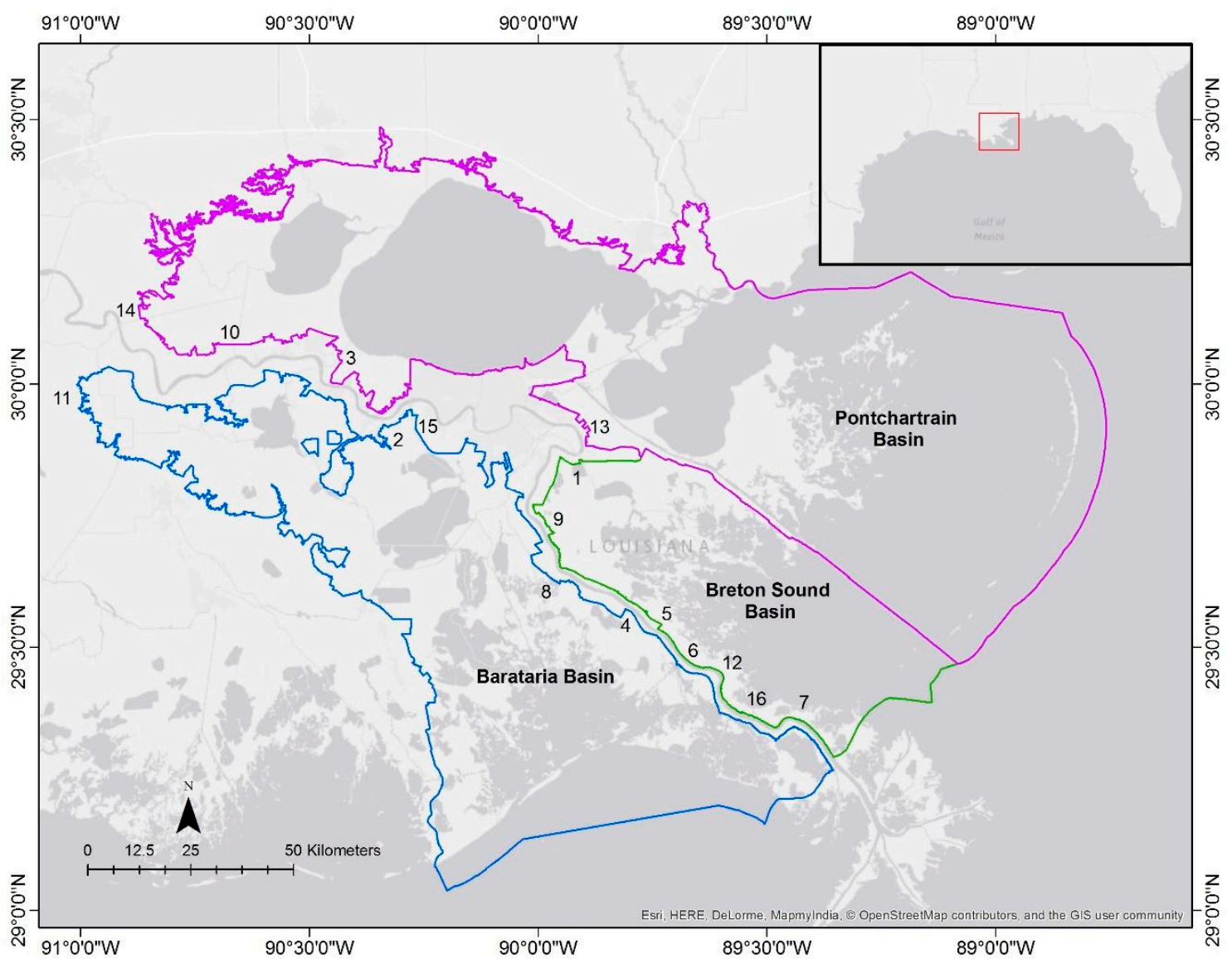

Figure 1. Location map showing the estuarine basins and the location of existing or planned connections between the Mississippi River and estuarine basins. See Table 1 for more information.

The higher $E_{x y}$ values allowed for more exchange between compartments and lower values allowed for less exchange between compartments. In addition to adjusting the dispersion-diffusion coefficient, the salinity predictions were improved by the addition of a term in the hydrodynamic code that replaced the original central-difference method used for salinity convection with a first-order upwinding scheme [29]. This scheme was used for compartments with typical river/canal flows, where upwinding was an appropriate approximation, as compared to slower estuarine/marsh flow regimes where the upwinding scheme was not applied. This addition of the upwinding technique greatly increased the stability of salinity predictions. Further discussion and analysis of the ICM methodology, calibration, validation, model performance and analysis are provided in the Supplementary Materials as well as several peer reviewed articles [24-26,30-34] and technical reports [35-41].

This paper focuses on six sets of analyses. Five of the six simulations were analyzed using the 50-year flow hydrograph used in the 2017 Coastal Master Plan analysis, whereas the current conditions simulation used the observed flow hydrograph for 2006 through 2013. Three distinct Mississippi River flow conditions were identified from the historical river discharge data from 1964 to 2013 and were used in single year model runs for some of the analysis. Figure 2 shows the daily mean flow in the Mississippi River at Tarbert Landing, from 1964 to 2013. Figure 3 shows the annual mean flow anomaly (i.e., deviation from the long-term mean) for the Mississippi River for this 50-year flow hydrograph. A low river year (1988, elapsed year 25), a high river year (1993, elapsed year 30), and an average river year (1992, elapsed year 29) were selected between year 25-35. These river years were used to examine the effects of project configurations under a range of river flow conditions for some of the simulations described here.

Table 1 shows the operation regimes for diversions and other river outlets to estuarine basins. The operational flow rates for most passes, cuts, and diversions on the Mississippi River were based 
upon the flow in the river at each respective pass/diversion location. Therefore, the operation of any diversion was impacted by all operated diversions located upstream.

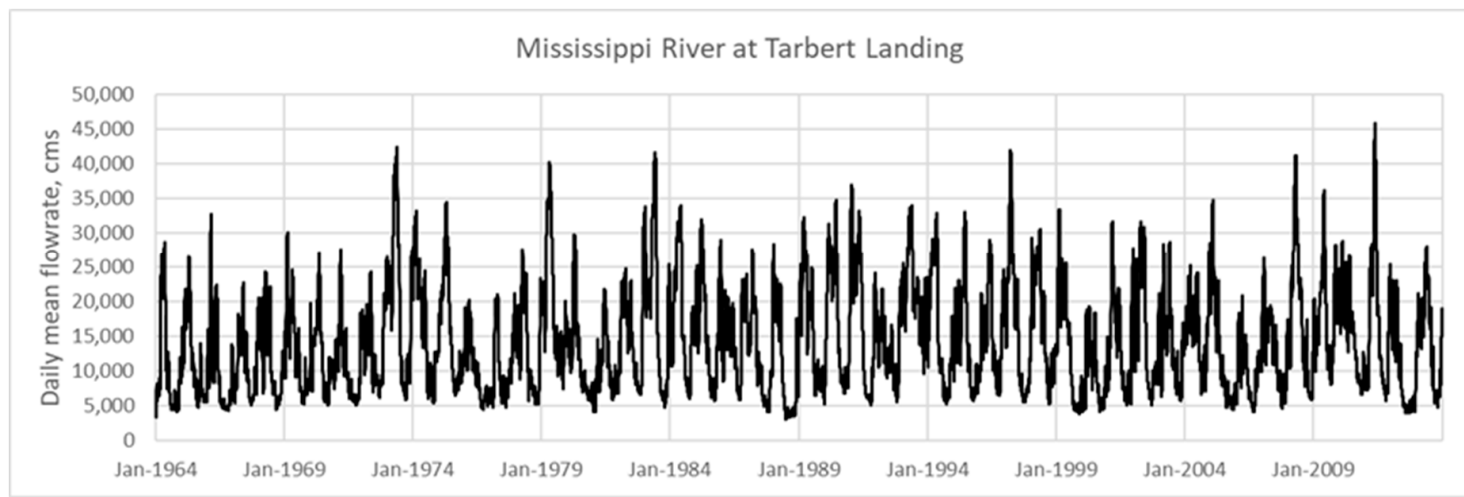

Figure 2. Daily mean flow in the Mississippi River at Tarbert Landing, 1964 to 2013.

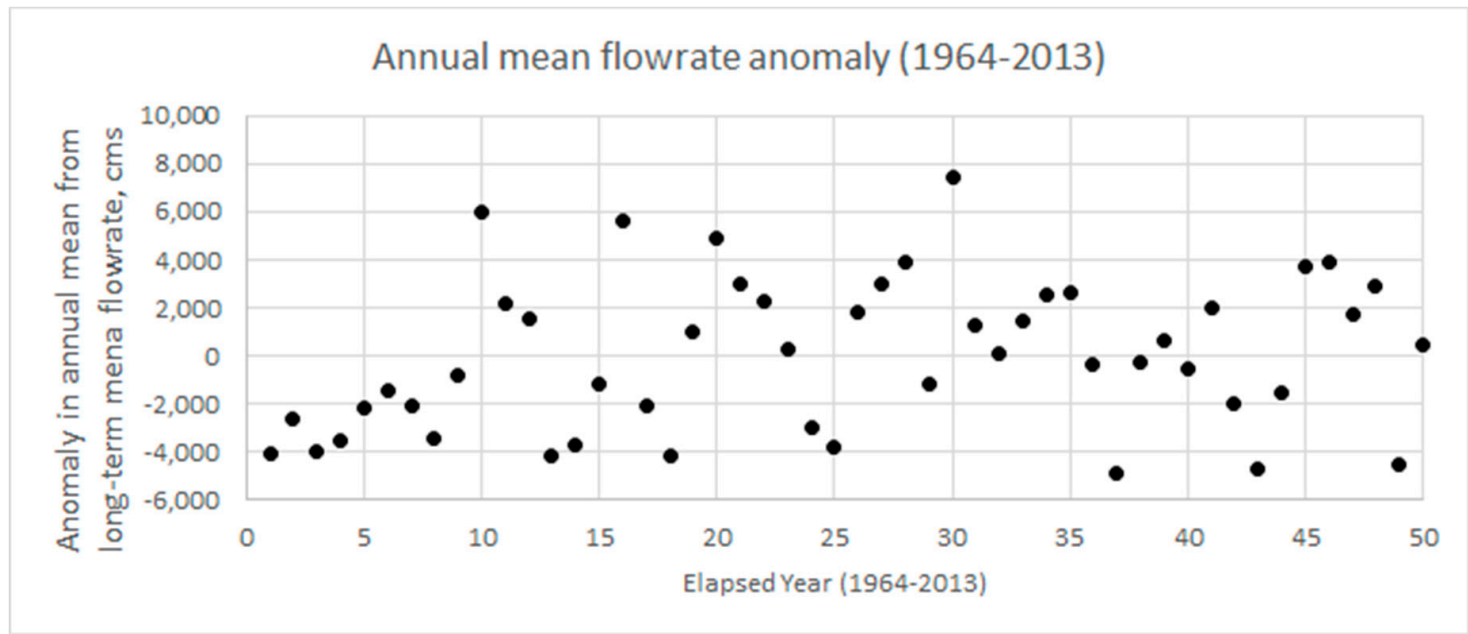

Figure 3. Annual mean flow anomaly from 1964 to 2013.

All of the analyses presented here (with the exception of the current conditions run, which used observed boundary conditions) were conducted using the medium scenario for the 2017 Coastal Master Plan [35]. The medium scenario uses $0.63 \mathrm{~m}$ of eustatic sea-level rise (ESLR) from 2015 through the end of 2064. The acceleration term increased over time, and the rate corresponded to $1.5 \mathrm{~m}$ of ESLR by 2100 compared to the 1992 sea level. The relative sea-level rise rates were assigned based upon these ESLR rates and subsidence values, which varied spatially across the model domain [42]. For the area included in this study, the subsidence ranges from $2.6 \mathrm{~mm} /$ year in the Upper Pontchartrain basin to $17 \mathrm{~mm} /$ year in the Birdsfoot Delta (refer to Figure S1 in Supplementary Materials: ICM Overview, for a map showing subsidence zones for coastal Louisiana used in this analysis).

A set of simulations was designed to explore a range of uses of Mississippi River water and sediment. The locations of existing and planned connections from the Mississippi River to the estuarine basins are shown in Figure 1 and their configurations are shown in Table 1.

The six simulations conducted for this analysis were:

1. Current Conditions. Before the ICM was used to assess future hydrologic and landscape conditions throughout coastal Louisiana, the ICM-Hydro subroutine was run from 2006 to 2013 using observed salinity and water level data collected across coastal Louisiana. The descriptions of the data used for this run and discussions on general model performance and limitations can be found in previously published literature [28,30-32]. This run is used to illustrate the current pattern of salinity fluctuations within the estuaries, against which simulations that include sea-level rise can be compared. 
2. Simulations of Future Conditions with Varying Levels of Freshwater Inflow.

a. Future Without Action Run (FWOA). The ICM was run for a future 50-year period without any potential future projects included. This simulation is termed the future without action (FWOA). In the FWOA, all sediment and freshwater diversions that were already built were implemented in the model. A full discussion of all boundary conditions assumed for this 50-year future condition is available in Brown et al., [28]. This run is used to demonstrate the effects of relative sea-level rise on the estuarine salinity gradient in the absence of additional freshwater inflow.

b. Base Run with Both Mid-Basin Sediment Diversions (Base Run). This 50-year model run includes all diversions that are currently in some phase of the engineering and design process (e.g., Mid-Barataria sediment diversion, Mid-Breton sediment diversion, and Maurepas freshwater diversion) and represents a likely future condition against which the need for additional management of river-estuarine can be assessed. In the base run, these diversions were implemented in addition to the existing diversion included in FWOA (Table 1). This run is used to demonstrate the effects of the diversion projects which are expected to be built within the next 5 years in the context of future sea-level rise.

c. All 2017 Master Plan Diversions (MP17). This simulation shows the potential effect of all 2017 Coastal Master Plan diversions working together over a 50-year period. This includes 5 diversions in addition to those included in the base run (Table 1).

3. Simulations examining connectivity between the river and estuary. In addition to the above multi-year simulations, several single-year simulations were also conducted to explore specific options for adjusting connectivity between the river and the estuary and the effects of diversion operation on sediment delivery, which is a key factor in using sediment diversions to combat the effects of future sea-level rise. One simulation explores the modified exchange between the Mississippi River and Breton Sound by comparing the effect of a single larger diversion point versus multiple smaller exchange points. The currently active exchange points with the Mississippi River (e.g., Caernarvon Freshwater Diversion, Mardi Gras Pass, Bohemia Spillway, Fort St. Philip, etc. see Table 1) were modeled as inactive with the flow being maintained in the main channel of the Mississippi River.

4. Simulations examining diversion operations to deliver fine sediment. Many of the planned diversions have been justified on the basis of delivering sediment to the estuarine basins [43]. In addition to the information developed on sediment delivery using the simulations described above, an additional ICM run was conducted to assess the use of a diversion operational regime focused on the delivery of fine sediment, i.e., less focused on maximizing water flow during peak river flows as for the Mid-Breton and Mid-Barataria diversion (Table 1). This simulation used the Central Wetlands diversion (Table 1, Figure 3) as an example and was conducted on three years which represent years with low, average, and high rates of Mississippi River flow.

To examine the effect of diversions over time as the relative sea-level rise progresses, the salinity gradients within the receiving basins plots were constructed showing the area of the basin (wetland and open water combined) subject to different salinity levels. Six bins were identified representing different salinity ranges. These salinity ranges were selected on the basis of salinity tolerance of seven wetland species which have previously been used to assess the effects of Mississippi River diversions [44]. The range in salinity values in which these species are optimally located (as defined by the LAVegMod model rules [25]) are shown in Figure 4. The daily salinity values for the growing season for the Louisiana coastal wetland vegetation were used to calculate the area of the basin, experiencing the salinity range for each bin in each year of the simulation. The model output for each ICM-Hydro compartment, which included both open water and marsh areas, was summarized based on three ecoregions shown in Figure 1. 


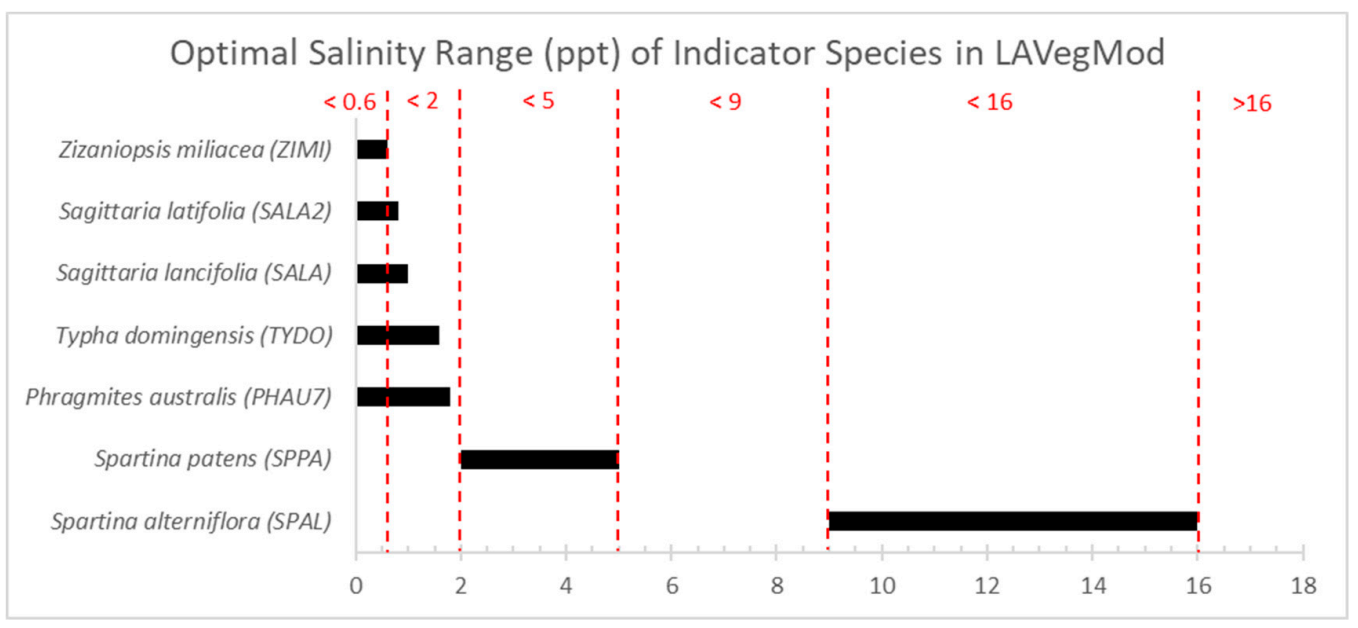

Figure 4. Salinity ranges considered optimal for seven indicator wetland vegetation species.

\section{Results}

\subsection{Current Conditions}

A comparison across the basins (Figure 5) shows the differences in the penetration of salinity into the basins. Both Pontchartrain and Barataria show extensive areas with salinity 16-35 ppt in all years, while for four of the years this salinity range does not occur in Breton. This is due to the proximity of Breton to the Mississippi River and the many small connections (see further analysis of the effects of these connections below).

Breton is also different at the lower end of the salinity range. Both Pontchartrain and Barataria extend inland some distance, are larger in size (increasing freshwater inputs through precipitation) and receive some municipal stormwater runoff. Pontchartrain also received freshwater inflow from tributary streams. Both Barataria and Pontchartrain include areas $<0.6 \mathrm{ppt}$ in all years in this run. However, the conditions in 2006, 2007 and 2012 eliminate this zone in Breton.

The period shown in Figure 5 included both a high flood year (2011) and a low river flow year (2012) as shown in Figure 3. However, there is a substantial change in the salinity distribution in only one of the three basins. The high flow in 2011 does not increase the area $<0.6$ ppt in any basin indicating the limited connections between the Mississippi River and estuarine basins in the current condition. However, Breton which has several small connections, does show a substantial decrease in the area with salinities $<2$ ppt in 2012 during the low flow year.

\subsection{Simulations of Future Conditions with Varying Levels of Freshwater Inflow}

Three of the simulations progressively increase the exchange between the Mississippi River and estuarine basins (Table 1). Table 2 summarizes the differences in the distribution of salinity for decadal intervals during the 50-year model runs, showing the relative area of the basins for three different salinity ranges (based on the six bins described above) for ease of comparison.

Table 2. Relative area of each basin subject to three salinity ranges by decade for future without action (FWOA), the base run and MP17 simulations.

\begin{tabular}{|c|c|c|c|c|c|c|c|c|c|}
\hline \multicolumn{10}{|c|}{ FWOA } \\
\hline & \multicolumn{3}{|c|}{ Pontchartrain } & \multicolumn{3}{|c|}{ Breton } & \multicolumn{3}{|c|}{ Barataria } \\
\hline & $<2 \mathrm{ppt}$ & 2-16 ppt & $>16 \mathrm{ppt}$ & $<2 \mathrm{ppt}$ & $2-16 \mathrm{ppt}$ & $>16 \mathrm{ppt}$ & $<2 \mathrm{ppt}$ & $2-16 \mathrm{ppt}$ & $>16 \mathrm{ppt}$ \\
\hline Year 10 & $53 \%$ & $47 \%$ & $0 \%$ & $54 \%$ & $46 \%$ & $0 \%$ & $60 \%$ & $27 \%$ & $13 \%$ \\
\hline Year 20 & $53 \%$ & $47 \%$ & $0 \%$ & $48 \%$ & $52 \%$ & $0 \%$ & $54 \%$ & $31 \%$ & $15 \%$ \\
\hline Year 30 & $54 \%$ & $46 \%$ & $0 \%$ & $54 \%$ & $46 \%$ & $0 \%$ & $49 \%$ & $35 \%$ & $16 \%$ \\
\hline Year 40 & $50 \%$ & $50 \%$ & $0 \%$ & $27 \%$ & $73 \%$ & $0 \%$ & $25 \%$ & $45 \%$ & $29 \%$ \\
\hline Year 50 & $31 \%$ & $66 \%$ & $3 \%$ & $17 \%$ & $83 \%$ & $0 \%$ & $4 \%$ & $52 \%$ & $44 \%$ \\
\hline
\end{tabular}


Table 2. Cont.

\begin{tabular}{|c|c|c|c|c|c|c|c|c|c|}
\hline \multicolumn{10}{|c|}{ Base Run-Mid-Basin Diversions } \\
\hline & \multicolumn{3}{|c|}{ Pontchartrain } & \multicolumn{3}{|c|}{ Breton } & \multicolumn{3}{|c|}{ Barataria } \\
\hline & $<2 \mathrm{ppt}$ & $2-16 \mathrm{ppt}$ & $>16 \mathrm{ppt}$ & $<2 \mathrm{ppt}$ & $2-16 \mathrm{ppt}$ & $>16 \mathrm{ppt}$ & $<2 \mathrm{ppt}$ & $2-16 \mathrm{ppt}$ & $>16 \mathrm{ppt}$ \\
\hline Year 10 & $58 \%$ & $42 \%$ & $0 \%$ & $55 \%$ & $45 \%$ & $0 \%$ & $65 \%$ & $25 \%$ & $10 \%$ \\
\hline Year 20 & $54 \%$ & $46 \%$ & $0 \%$ & $55 \%$ & $45 \%$ & $0 \%$ & $66 \%$ & $24 \%$ & $10 \%$ \\
\hline Year 30 & $58 \%$ & $42 \%$ & $0 \%$ & $70 \%$ & $30 \%$ & $0 \%$ & $72 \%$ & $18 \%$ & $10 \%$ \\
\hline Year 40 & $50 \%$ & $50 \%$ & $0 \%$ & $49 \%$ & $51 \%$ & $0 \%$ & $60 \%$ & $28 \%$ & $12 \%$ \\
\hline Year 50 & $31 \%$ & $63 \%$ & $6 \%$ & $29 \%$ & $71 \%$ & $0 \%$ & $56 \%$ & $29 \%$ & $16 \%$ \\
\hline \multicolumn{10}{|c|}{ All 2017 Master Plan Diversions } \\
\hline & \multicolumn{3}{|c|}{ Pontchartrain } & \multicolumn{3}{|c|}{ Breton } & \multicolumn{3}{|c|}{ Barataria } \\
\hline & $<2 \mathrm{ppt}$ & $2-16 \mathrm{ppt}$ & $>16 \mathrm{ppt}$ & $<2 \mathrm{ppt}$ & $2-16 \mathrm{ppt}$ & $>16 \mathrm{ppt}$ & $<2 \mathrm{ppt}$ & $2-16 \mathrm{ppt}$ & $>16 \mathrm{ppt}$ \\
\hline Year 10 & $61 \%$ & $39 \%$ & $0 \%$ & $58 \%$ & $42 \%$ & $0 \%$ & $67 \%$ & $23 \%$ & $10 \%$ \\
\hline Year 20 & $58 \%$ & $42 \%$ & $0 \%$ & $55 \%$ & $45 \%$ & $0 \%$ & $67 \%$ & $23 \%$ & $10 \%$ \\
\hline Year 30 & $61 \%$ & $39 \%$ & $0 \%$ & $70 \%$ & $30 \%$ & $0 \%$ & $76 \%$ & $14 \%$ & $10 \%$ \\
\hline Year 40 & $50 \%$ & $50 \%$ & $0 \%$ & $48 \%$ & $52 \%$ & $0 \%$ & $63 \%$ & $27 \%$ & $10 \%$ \\
\hline Year 50 & $36 \%$ & $58 \%$ & $6 \%$ & $29 \%$ & $71 \%$ & $0 \%$ & $60 \%$ & $30 \%$ & $10 \%$ \\
\hline
\end{tabular}

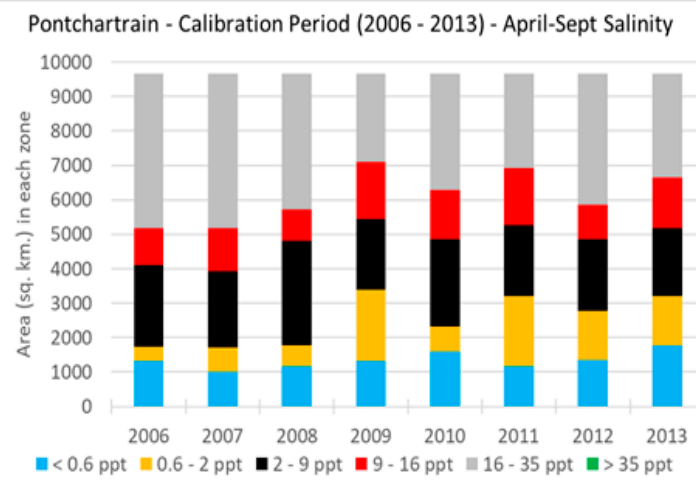

Breton Sound - Calibration Period (2006 - 2013) - April-Sept Salinity 3000
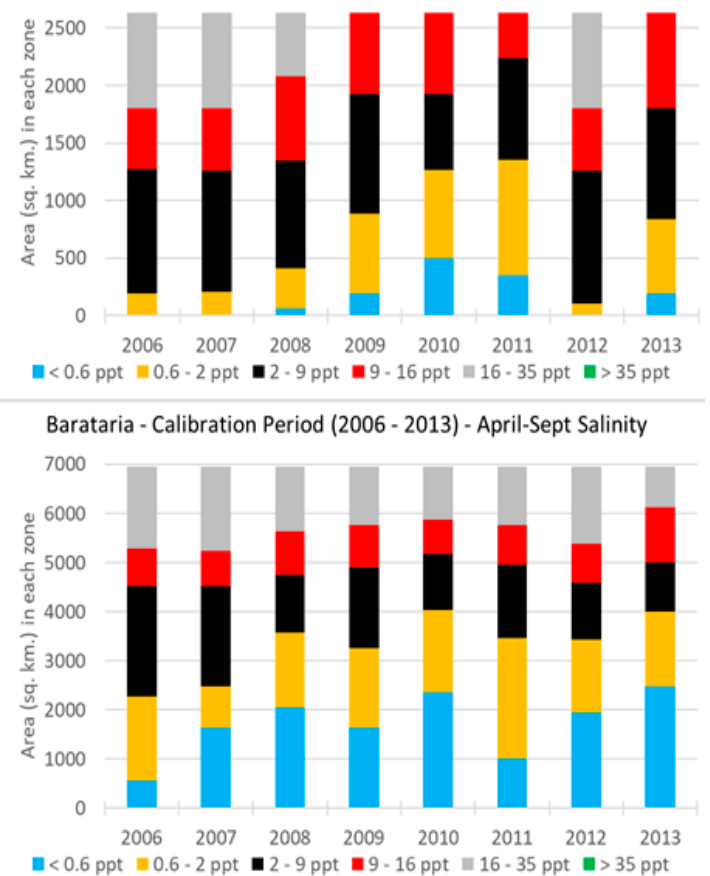

Figure 5. April to September salinity region variation in Pontchartrain (top), Breton (middle) and Barataria (lower) for the current conditions simulation. 
The FWOA run maintains the same connections between the basins and Mississippi River as the current conditions simulation. However, the 50-year simulation includes the effects of the relative sea-level rise and the changing wetland landscape within the basins [33]. Under FWOA, all basins show an increase over time in the proportion of the basin in the 2-16 ppt range, and both Pontchartrain and Breton show an increase in the area $>16$ ppt by year 50 . The rate of eustatic sea-level rise accelerates over time in the simulation and is assumed to be the lead cause of that significant increase in salinities in the last decade.

The base run shows the same increase in salinity levels in Pontchartrain, Breton, and Barataria for April-September as found in FWOA with some individual years, fresher or more saline. The simulation including all the 2017 Master Plan diversions does not result in a substantially different salinity regime compared to the base run, mostly because both simulations include several diversion projects that divert large freshwater volumes to the basins. The operation plans are different between the simulations but not sufficiently to create major differences in the salinity regime. Table 2 shows the least amount of area $>16$ ppt at year 50 in this run compared to the other runs in Barataria, with the other basins being similar.

The annual snapshots shown in Table 2 mask the extensive interannual variation, and the differences in the response among the basins to events included in the 50-year boundary conditions. Of note, here is a severe drought (low rainfall) in the simulation in years 42-43. Figure 6 shows the effect of this drought in Pontchartrain in years $42-43$ for the three simulations. For each simulation, these years show the greatest extent $>16 \mathrm{ppt}$ and the least extent $<0.6 \mathrm{ppt}$.

Figure 6 shows a few major trends over time in Pontchartrain with substantial interannual variability, as might be expected where there are connections to riverine inflows. The last 15 years of the simulations show a generally smaller area of $<0.6 \mathrm{ppt}$. In Pontchartrain, there appears to be an increase in the frequency of years with large areas $>16 \mathrm{ppt}$ in the later years which may be associated with the progressive influence of sea-level rise. This occurs in all three simulations and may be more related to the changes in freshwater from tributary inflows to the basin from inland streams, which remains the same for all simulations, rather than the river diversion inflows.

The changes in the Breton basin are shown in Figure 7. This basin has no inputs of freshwater apart from the precipitation and multiple relatively small controlled or uncontrolled connections to the Mississippi River (Table 1). The last 15 years of the simulations show a generally smaller area of $<0.6 \mathrm{ppt}$ in all simulations shown in Figure 7, and in FWOA there is also a decrease in the area $<2$ ppt. The FWOA also shows some incursion of water $>16 \mathrm{ppt}$ in isolated years in the last decade in contrast to earlier years of the simulation.

With the mid-basin diversion, the area in Breton $<0.6$ ppt increases compared to FWOA, showing that the large diversion has a greater impact on salinity than the existing connections (see next section). However, there are more years in the base and MP17 runs compared to FWOA, especially early in the simulations, when Breton includes areas $>16$ ppt. This seems counterintuitive when more freshwater is entering the basin through the diversion. However, as diversions into Barataria are also operating in these simulations, the flow toward the mouth of the Mississippi is diminished, reducing the discharge through distributaries in the Birdsfoot Delta, and increasing salinity in the lower parts of the Breton basin (Figure 3). 

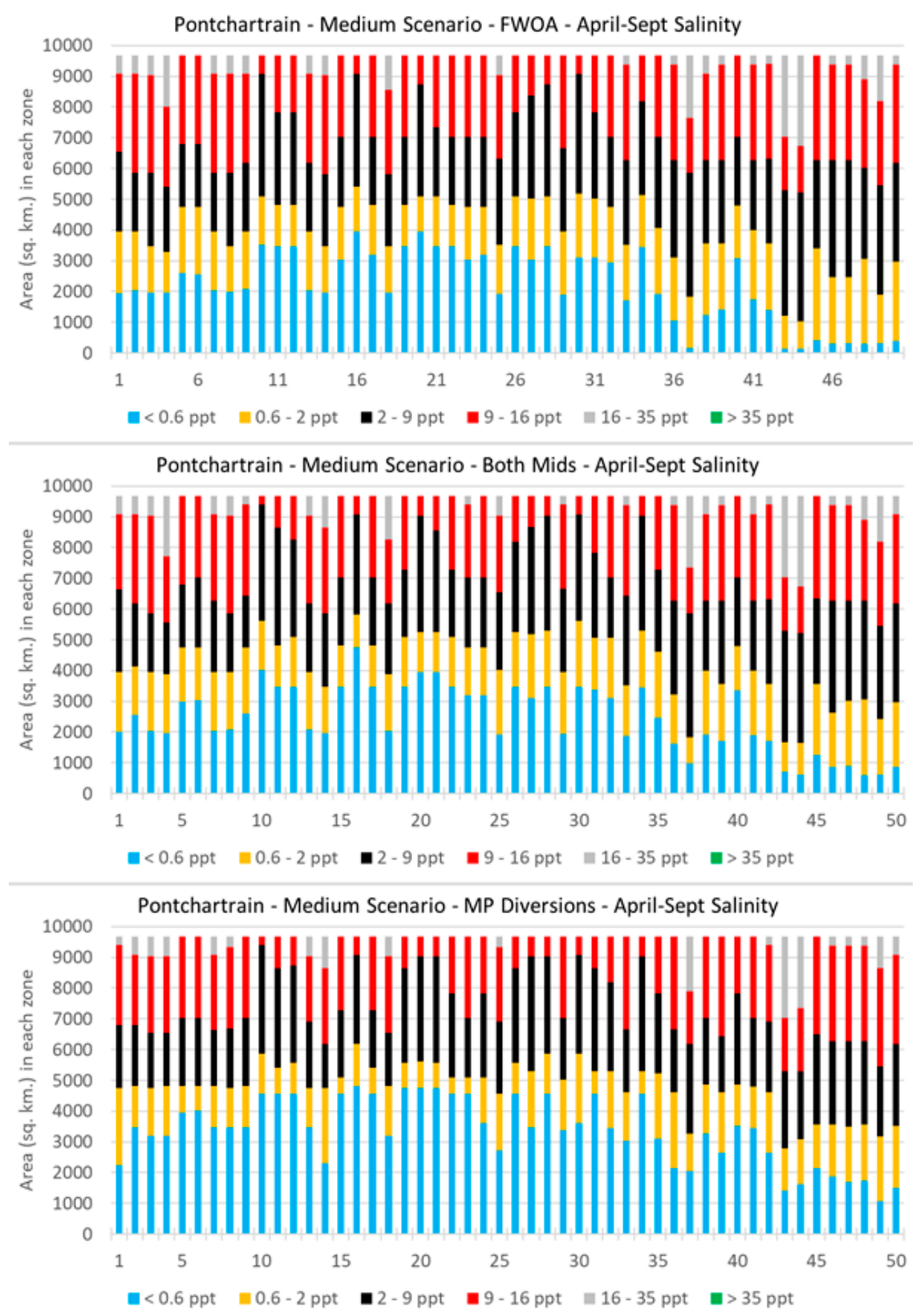

Figure 6. April to September salinity region variation in Pontchartrain for runs with varying levels of freshwater inflow

Barataria shows a very different pattern from the other basins, especially under FWOA (Figure 8). The FWOA run maintains the same connections between the basins and Mississippi River as current conditions. The 50-year simulation includes the effects of the relative sea-level rise and the changing wetland landscape and these effects are most dramatically shown in FWOA. There is a major increase in the extent of the basin with 16-35ppt salinity after year 30 (Figure 8). This period also shows a major decrease in the area $<0.6 \mathrm{ppt}$. In the last few years of the simulation, only a small area of the basin experiences salinities $<2 \mathrm{ppt}$. 

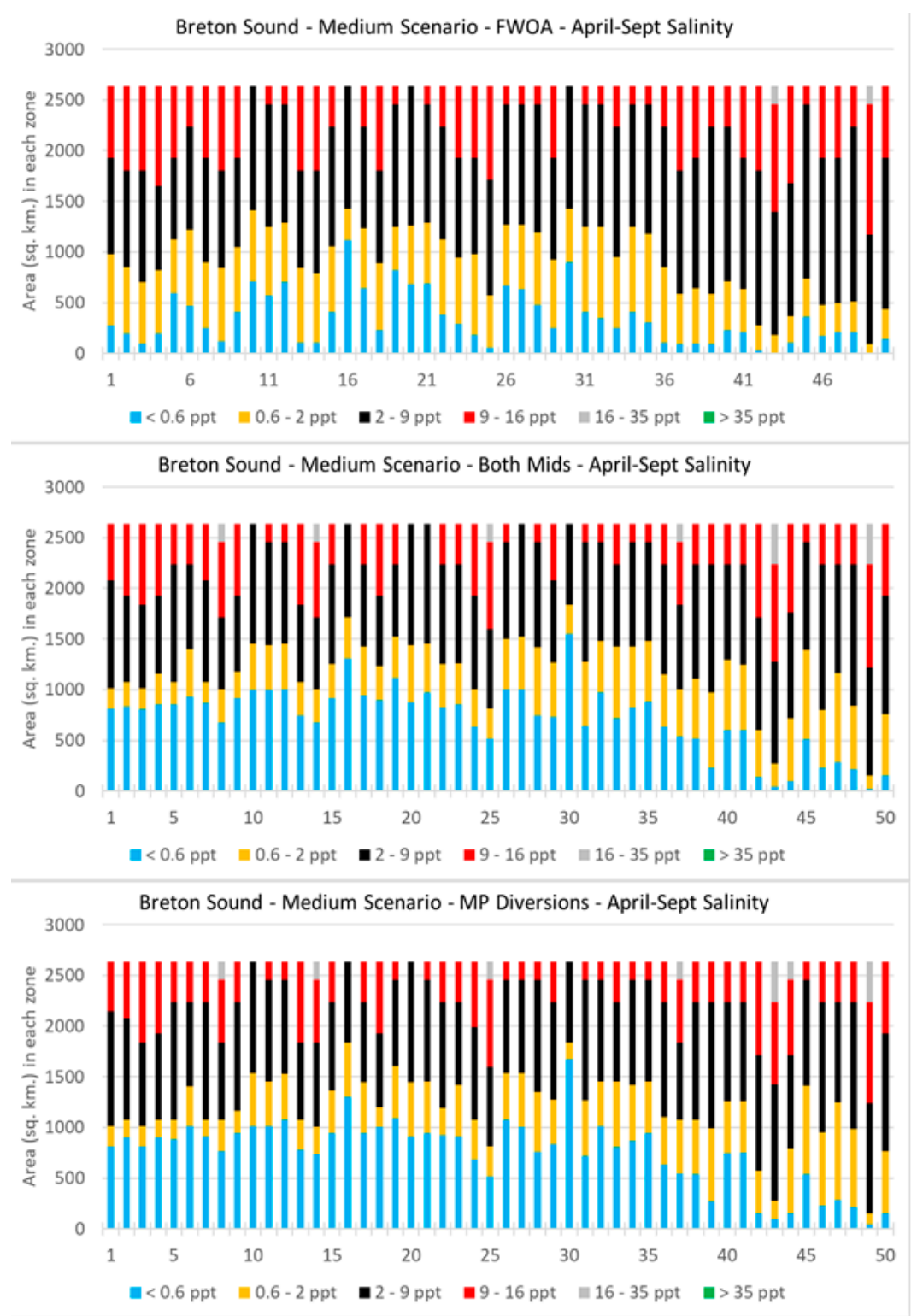

Figure 7. April to September salinity region variations in Breton for runs with varying levels of freshwater inflow.

With the diversions operating, Barataria does not experience the dramatic increase in the areas $>16$ ppt found in FWOA. Figure 8 shows remarkably little change over time. There is an increase for most of the 50-year simulation in the extent $<0.6 \mathrm{ppt}$ in Barataria in the base run but during the drought period, a large area $<2$ ppt remains. The MP17 simulation includes an additional diversion into the Barataria basin at Ama (Table 1, Figure 1) which appears to have little effect on the salinity distribution for most of the simulation, but reduces the effect of the drought. Even with this diversion, there are still conditions in specific years later in the simulation, that dramatically reduce the area of the basin $<0.6 \mathrm{ppt}$. 

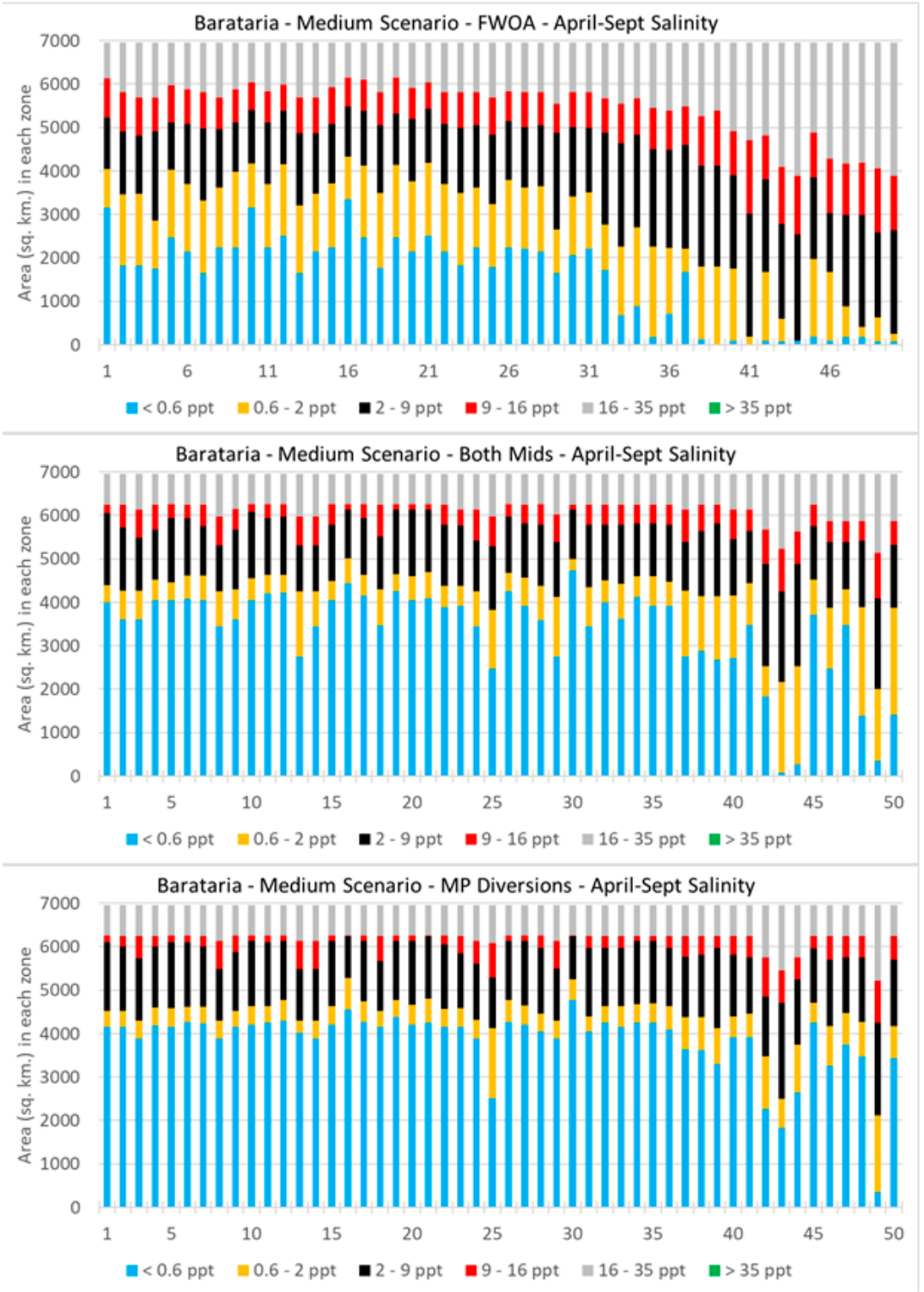

Figure 8. April to September salinity region variations in Barataria for runs with varying levels of freshwater inflow.

\subsection{Modified Exchange between the Mississippi River and Breton Sound}

The currently active exchange points (distributaries) between the Mississippi River and Breton Sound (e.g., Caernarvon Freshwater Diversion, Mardi Gras Pass, Bohemia Spillway, Fort St. Philip, etc.) were modeled as inactive with the flow being maintained in the main channel of the Mississippi River and eventually reaching the Birdsfoot Delta. All other simulation conditions (including diversion operations) and environmental assumptions were as represented in the 2017 Coastal Master Plan FWOA and the base run (Table 1).

Figure 9 shows the salinity difference maps for the run with modified exchange compared to the base run at year 25 and 50, respectively. The simulation results show a salinity increase that extends east into the Lower Pontchartrain basin due to the reduced freshwater into Breton. The April-September salinity distribution plots in Figure 10 show the salinity gradient in Breton due to the disconnection from the Mississippi River, which shows a greater extent of saline bins compared to the base run (Figure 7) while little change is observed in Barataria or Pontchartrain. 

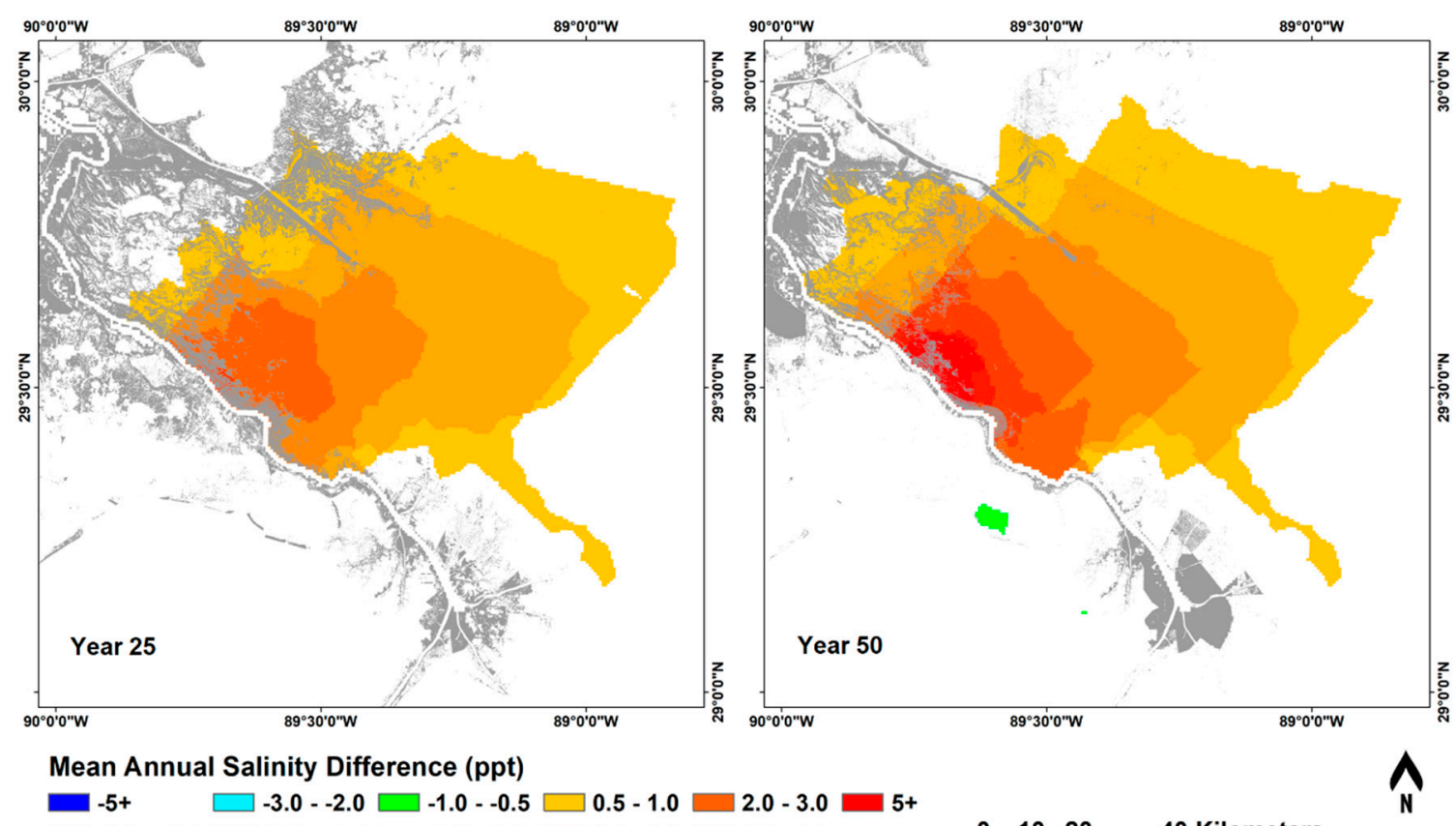

Mean Annual Salinity Difference (ppt)

- $-5+\square-3.0--2.0 \square-1.0--0.5 \square 0.5-1.0 \square 2.0-3.0 \square 5+$

$-5.0--4.0 \square-2.0--1.5 \square-0.5-0.0 \square 1.0-1.5 \square 3.0-4.0$

$0 \quad 1020 \quad 40$ Kilometers

Figure 9. The salinity difference when exchanges with Breton Sound through distributary channels downstream of the Mid-Basin diversions are reduced (modified exchange run compared to the base run with both Mid-Basin diversions) at year 25 (left) and year 50 (right). Eustatic sea level rise by year 25 was $0.33 \mathrm{~m}$ and $0.63 \mathrm{~m}$ by year 50 .

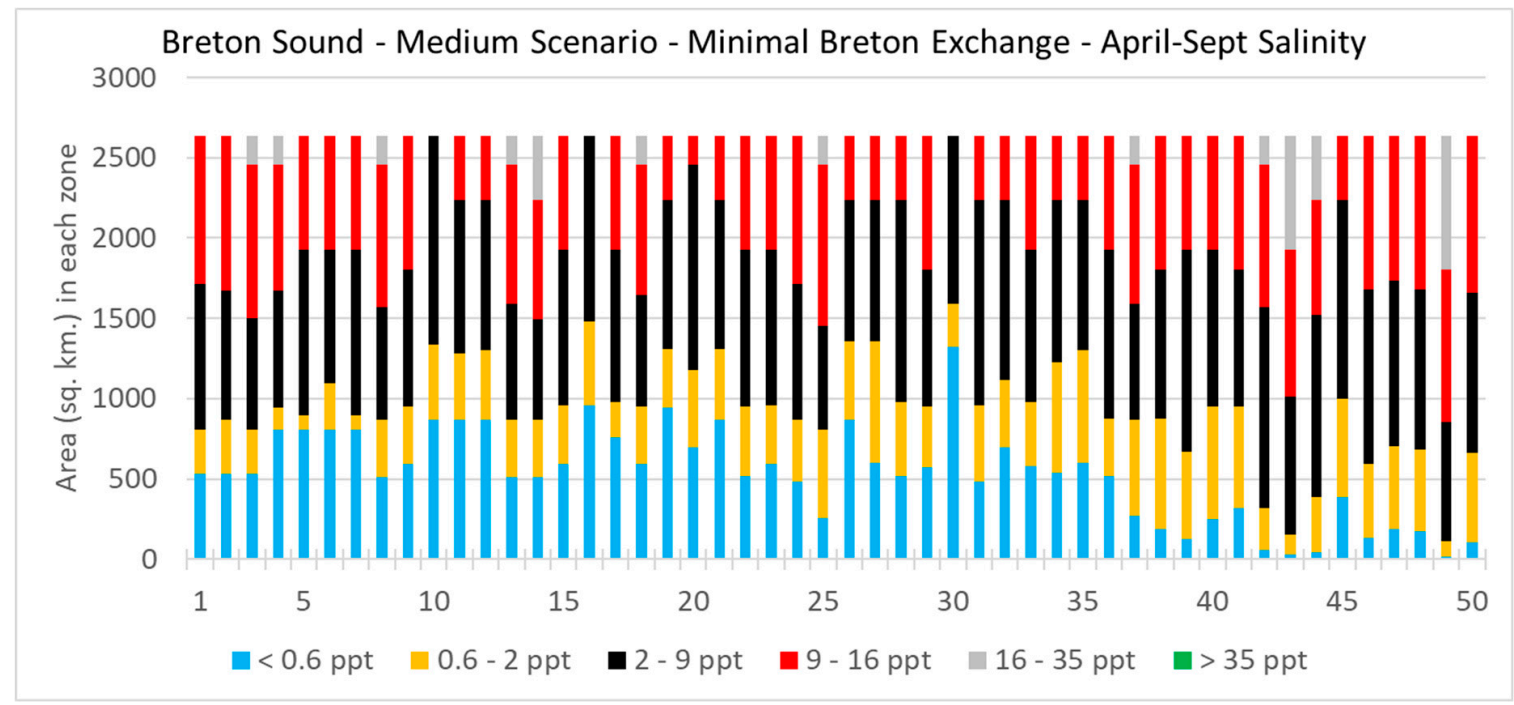

Figure 10. April to September salinity region variation in Breton Sound eco-region with minimal exchange between the Mississippi River and Breton Sound.

The vegetation coverage for the base run and minimal exchange for year 25 and 50 are shown in Figure 11. The vegetation in lower Breton Sound and along the east bank side of the Mississippi River converts towards a more saline type due to the freshwater reduction with the modified exchange as the direct freshwater input through Mardi Gras Pass and Fort St. Philip (Figure 3) are reduced. While less vegetated land is shown in year 50 as the effects of the sea-level rise and subsidence have resulted in land loss, a similar effect is apparent. At year 50, with $0.63 \mathrm{~m}$ of additional sea-level rise, the diversion alone (Modified Exchange in Figure 11) maintains fresh marsh in the upper part of the Breton basin but is insufficient to prevent saline marsh along the east bank of the river. 

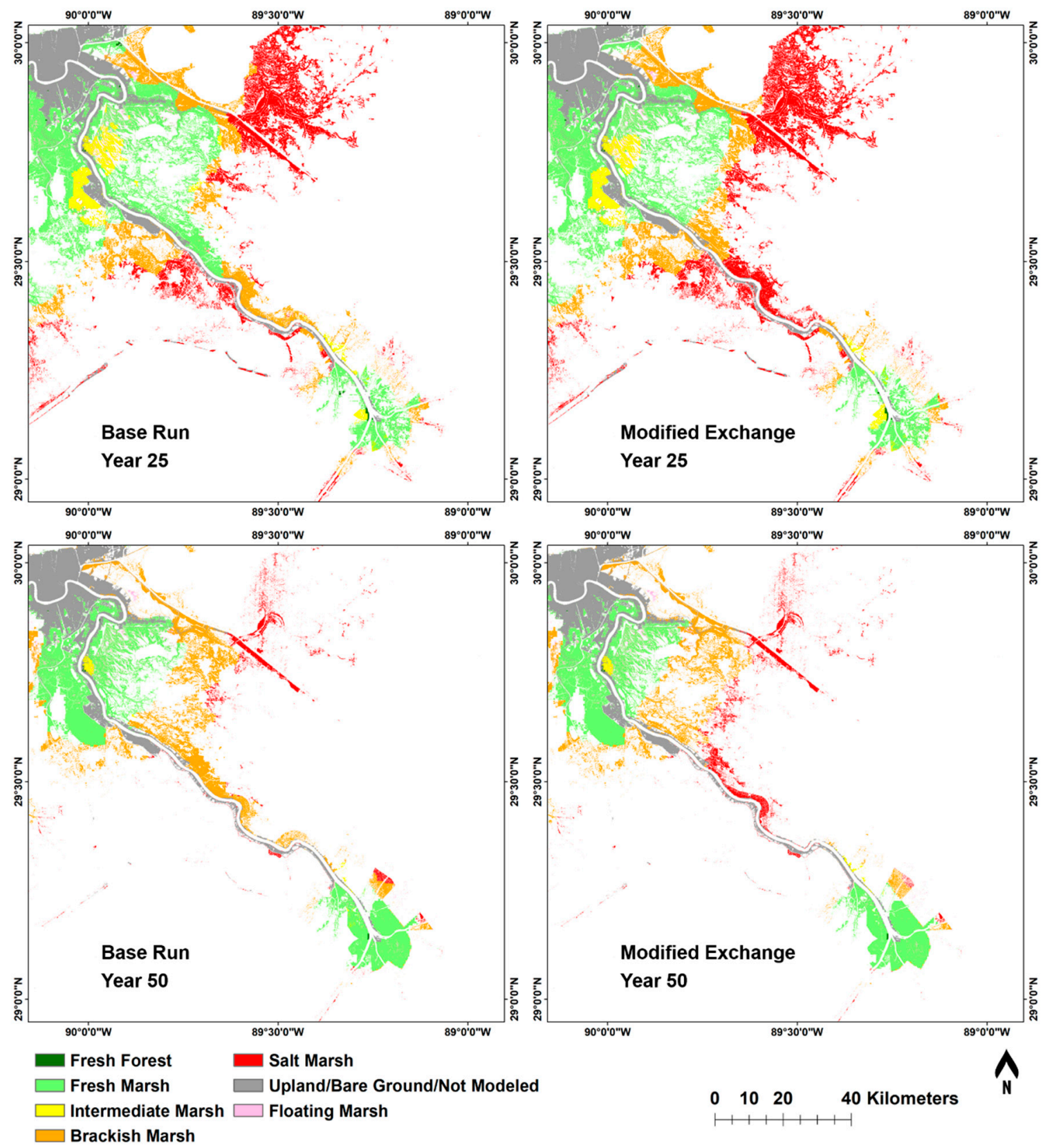

Figure 11. Vegetation coverage for base run with both of the Mid-Basin diversions (left) and the modified exchange run with both diversions active but other connections to Breton Sound reduced in flow capacity (right). Eustatic sea level rise by year 25 (top) was $0.33 \mathrm{~m}$ and $0.63 \mathrm{~m}$ by year 50 (bottom).

There is also a marked difference in the extent of the brackish marsh zone between year 25 and year 50 . At year 25 , this is a very narrow band in both simulations. The freshwater from the diversion and saline water from the Gulf squeeze out the brackish zone. However, as the sea-level rise progresses, saltwater penetrates further, mixing with the fresh conditions maintained by the diversion to produce a more extensive zone of brackish marsh. It should be noted that in addition to the vegetation shifts over time and under different freshwater exchange scenarios, there is a marked decrease in the amount of wetland area throughout lower Barataria and lower Breton basins under this assumed relative sea level rise scenario. This conversion of wetland area to open water is a consequence of persistent inundation and salinity penetration due to the combined effects of eustatic sea level rise and subsidence [33]. 


\subsection{Operational Regime and Sediment Delivery}

The purpose of most planned river diversions in Louisiana is to provide sediment for rebuilding of coastal wetlands and their maintenance under a future sea-level rise [45]. Their location and design are often optimized based on the potential for delivery of sand from the river through the diversion structure [46,47]. Table 3 presents the cumulative suspended sand load (not including bedload or fines in suspension) diverted for the simulations described above. These observations also point to the need for careful management of the operation of proposed restoration strategies (with dynamic components).

Table 3. Suspended sand load diverted from the Mississippi River for each of the simulations (total over 50 years).

\begin{tabular}{ccc}
\hline $\begin{array}{c}\text { Sand Load Diverted from the Mississippi River } \\
\text { (Million Tonnes) }\end{array}$ & Breton & Barataria \\
\hline Base Run (two Mid-Basin diversions) & 136.7 & 47.7 \\
\hline All 2017 Master Plan Diversions & 146.8 & 44.8 \\
\hline $\begin{array}{c}\text { Modified Exchange between the Mississippi River } \\
\text { and Breton Sound }\end{array}$ & 84.5 & N/A \\
\hline
\end{tabular}

These simulations reflect the combined influence of different combinations of diversions with and without various existing connections between the river and estuary, over 50 years. Table 3 shows greater potential for sand delivery into Breton, which may be the result of the Mid-Breton diversion being upstream of the Mid-Barataria diversion, reducing the flow available for distribution when they are both operating simultaneously.

Varying the operational regimes shown in Table 1 would modify these sand loads. However, as fine sediments are important for coastal marsh maintenance in the face of sea-level rise [45], an additional simulation was conducted to assess the effects of an operational regime and the river flow on fine sediment delivery. This simulation used the Central Wetlands diversion as an example (see Figure 1 for location). The single-year runs were conducted to examine the different configurations and operational rules. All other simulation conditions (including diversion operations-see Table 1) and environmental assumptions were as represented in the 2017 Coastal Master Plan FWOA and the base run.

Three Central Wetlands diversion configurations were evaluated:

1. The operation of $141 \mathrm{cms}$ assumed in the 2017 Coastal Master Plan was used.

2. The diversion was operated similar to the Mid-Barataria diversion in the base run (see Table 1)

3. The diversion opened when river flow was above $12,742 \mathrm{cms}$ with a discharge of $0.83 \%$ of the Mississippi River flow. This diversion to river ratio was determined as the sum of the total diversion discharge if it operated with a constant $141 \mathrm{cms}$ flowrate in 50-years and divided by the total river flow when the diversion is opened (river flow above $12,742 \mathrm{cms}$ ) in 50 years. The idea is to operate the diversion only during the high river condition while retaining the same total annual discharge volume as with a constant flowrate (configuration 1).

The diversion discharge for these three different operational configurations in the selected low, medium, and high river years (see Methods) are shown in Figure S1 in Supplementary Materials: ICM Simulation Settings. The three diversion operations were evaluated in these pre-selected river flow conditions and the sand concentration in the diverted water was set to zero in order to evaluate sediment accumulation from fine particles.

The fine sediment accumulation in the receiving basin for the Central Wetlands diversion for different diversion configurations in different river years are shown in Figure 12. 


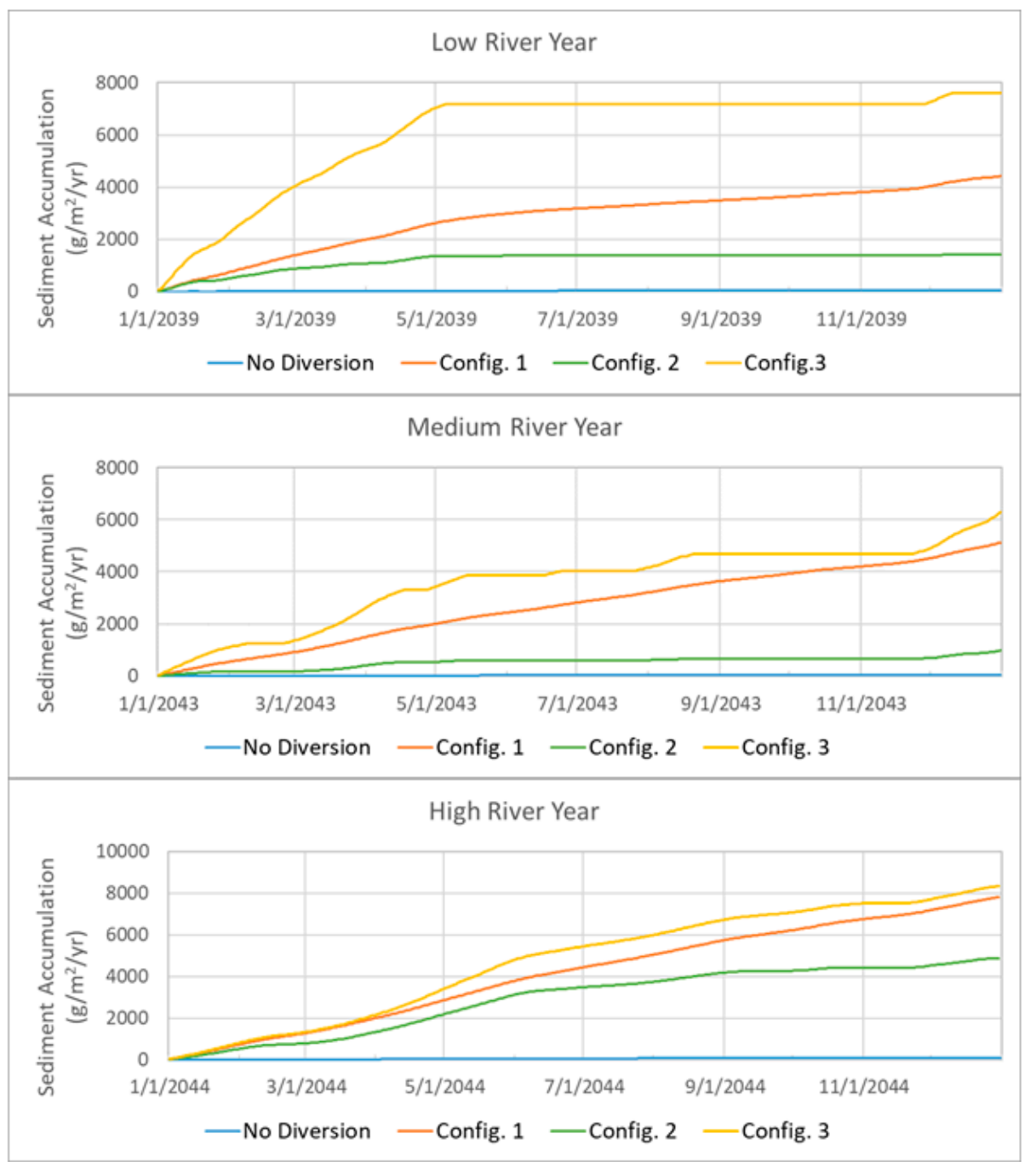

Figure 12. Sediment accumulation in the receiving compartment for the three Central Wetlands diversion configurations: A constant year-round flowrate of $141 \mathrm{cms}$ as modeled for the 2017 Master Plan (1), a flowrate activated when the river flow was above a given threshold with a maximum diverted rate of $141 \mathrm{cms}(2)$, and a diversion such that the annual volume diverted was equal to the annual volume diverted in configuration 1, but only during periods of peak flow in the river (3).

The receiving compartment is a $17 \mathrm{~km}^{2}$ tract of marsh (16\% of which is open water) on the east bank of the Mississippi River. The Central Wetlands tract is bounded on all sides by hydrologic barriers (flood walls, levees, roadways) and currently receives freshwater inflows from several pump station discharge lines which drain the eastern portions of New Orleans and neighboring municipalities. The sediment accumulation for diversion configuration 3 is higher compared to diversion configuration 1 and 2 in all simulated river conditions. Diversion configuration 3 performs better in low and medium river years when compared to the high river year.

The fifty-year simulations with diversion operational configuration 1 and 3 were conducted. Salinity in the immediate receiving area is highly influenced by the different operational configurations. As illustrated in Figure 13, operational configuration 1 resulted in a sustained low salinity in the diversion receiving area, while in operational configuration 3 , salinity is only slightly different from the no diversion condition. 


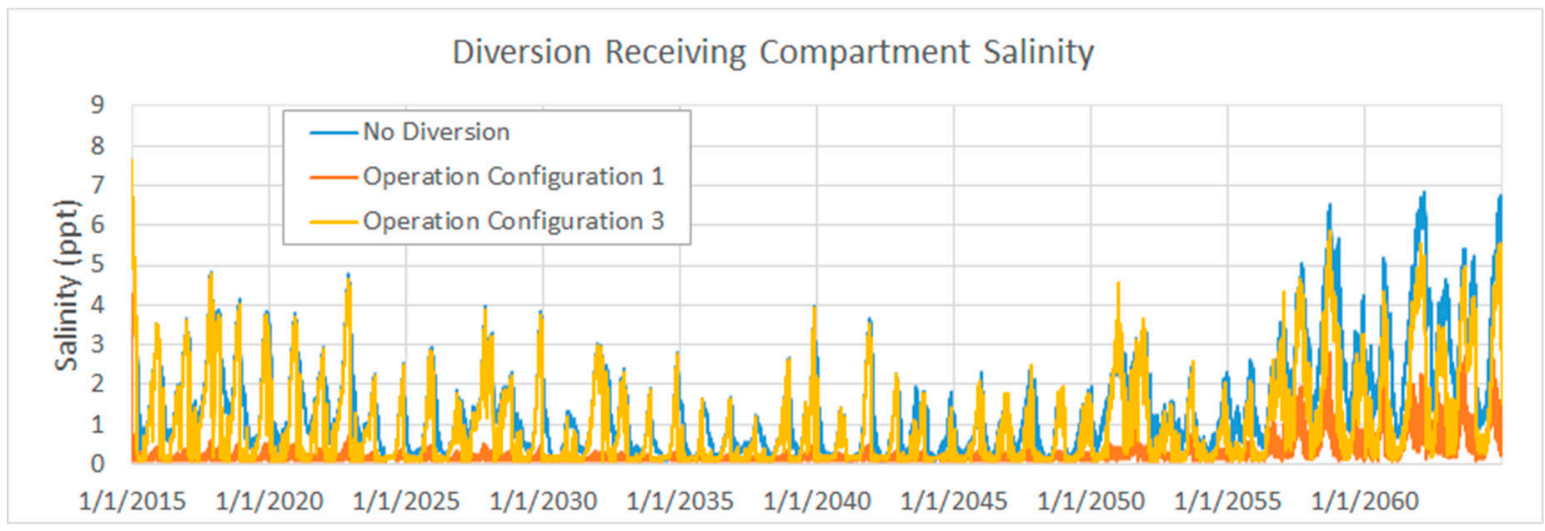

Figure 13. Salinity of the diversion receiving compartment for different operational configurations.

\section{Discussion}

\subsection{Future Effects of Relative Sea-Level Rise}

The effect of 50 years of sea-level rise on estuarine environments is often focused on the fate of the coastal wetlands and the impact of their loss of habitat for fish and wildlife [48-50]. The simulations described here show that the effects of the sea-level rise on these estuarine basins can be largely offset by more extensive use of river resources. Barataria basin (Figure 8) shows the most variation in salinity during the FWOA with a marked increase in later years of the simulation. It has a few existing connections to the Mississippi River, other than the Davis Pond freshwater diversion (Table 1), and no other freshwater inputs other than precipitation, stormwater runoff from local communities. Under FWOA, the fresher parts of the estuarine gradient, i.e., $<2 \mathrm{ppt}$, are greatly reduced and almost eliminated during drought years with low rainfall (Figure 8, Table 2).

Barataria also has a relatively intact chain of barrier islands, separated by tidal inlets, at the Gulfward margin (Figure 3). Barrier islands have been shown to modulate salinity in Louisiana estuaries [51]. The simulations described here do not discuss barrier island dynamics over time. Further, how the barrier shoreline is maintained in the future, as it also faces impacts from the sea-level rise, will be important for future salinities and the relative influence of diversion in the Barataria basin.

As this modeling has shown, the interaction of the future sea-level rise with other climatic factors is more complex. The inclusion of the drought years in year $42-43$ of the simulations showed that even in Pontchartrain where sea-level rise did not cause a major progressive increase in salinity $>16 \mathrm{ppt}$, the effect of a higher sea-level and reduced precipitation caused a temporary increase (Figure 6). The potential for adaptive operations for diversions to mitigate such events is discussed below. However, one other key influence on the issues discussed here is the effect of future climate change on Mississippi River discharge. The simulations included here are all based on the same 50-year record of the Mississippi River flow in order that the effects of diversions on the change in the estuaries due to the sea-level rise can be specifically explored. Studies have shown that trends in flooding on the Mississippi River are influenced by climate variability including the El Niño-Southern Oscillation and the Atlantic Multidecadal Oscillation [52], although predicting future river flow is challenging in large river systems [53].

\subsection{Effects of River Diversions on Estuarine Conditions}

This study has shown the influence of different magnitudes of river inflow on salinity gradients within the estuaries. The comparison of the future with only minor connections between the river and estuarine basin (FWOA) with two major diversions (base run) and then with additional diversions (MP17) for salinity distribution shows differences among the basins (Figures 5-7). For Pontchartrain (Figure 6) which does not directly receive additional inflows under the base run, the difference is the greatest in the last decade in the extent of the basin $<0.6 \mathrm{ppt}$. The incremental addition of diversions 
increases the area $<0.6 \mathrm{ppt}$. The area $<0.6 \mathrm{ppt}$, however, is smaller in extent than experienced in earlier decades, reflecting the progressive influence of the sea-level rise on the system. Even though the diversions are not directly influencing Pontchartrain basin, the extent of the freshwater influence from large diversions into Breton basin extends into lower Pontchartrain (Figure 9) perhaps ameliorating the penetration of higher salinities from the Gulf. There is much less difference in Pontchartrain among the higher salinity levels.

In contrast, in FWOA Breton (Figure 7) has fluctuating areas of $<0.6 \mathrm{ppt}$, likely due to fluctuations in the river flow (Figure 2) and the many small existing connections between the river and the basin (Table 1). Breton Sound basin both experienced fewer periods of the freshest salinity range, with three of the years having no portion of the basin with a mean salinity $<0.6 \mathrm{ppt}$. While in four other years, the basin had no portion with the mean salinities greater than $16 \mathrm{ppt}$. These freshening events occur during the wetter-than-average years of the flow in the Mississippi River. This was the case in five of the last six years in this simulation, 2008 through 2013 with the exception of 2012 (Figure 2). All five of these years were years with higher-than-average flowrates in the Mississippi River. The sixth year, 2012, was well below the average for the river flow. The sensitivity to the Mississippi River flow is due to the lack of any other pluvial source into Breton Sound. Additionally, the most Gulfward portions of the Breton Sound Basin are somewhat buffered from the open waters of the Gulf by both the distal barrier Chandeleur Islands enhancing the influence of Mississippi River fluctuations on salinities in the lower Breton basin [54]. This results in a basin that has less overall range to salinity in most years. However, the current conditions simulations ended in 2013, and did not include the flowrates for Mardi Gras Pass which initially formed during the 2011 flood. While one flow rating curve was used in this modeling (Table 1), the observed flows leaving this diversion and other connections to Breton had a noticeable impact on salinities in Breton, which was also seen in future simulations with these connections turned off (Figure 9).

Thus, the addition of the Mid-Breton diversion in the base run increases the freshwater area $<0.6$ ppt. However, Figure 7 also shows little change in the salinity zones between 2 and 16 ppt. This is shown in the vegetation patterns for year 25 (Figure 11) and the greater brackish area shown in Figure 11 at year 50 comes at the expense of the freshwater areas, the latter of which is limited in all three simulations in the last decade (Figure 7). Even the addition of the Lower Breton diversion (Table 1, Figure 1) in the MP17 simulation does not substantially change the basin scale conditions in the last decade, although there is likely localized freshening.

\subsection{Effect on Estuarine Fisheries}

Estuaries are an important habitat for the Gulf of Mexico's commercial and recreational fisheries with $97 \%$ (by weight) depending on estuaries for some part of their life cycle [55]. The importance of the freshwater inflow to estuarine ecosystems is widely recognized [56-58]. Often the focus of concern is the upstream impoundment of streams for water supply or flood management $[59,60]$ but in the estuarine basins discussed here, which have been essentially isolated from riverine inflows for more than a century due to river management in the delta plain, the key issue is where, when, and how much inflow is required to meet certain goals and avoid undesirable outcomes for other parts of the ecosystem [61].

The existing diversions have changed the aquatic ecology of their receiving area. Studies of Davis Pond and Caervarvon have examined the effects of diversion influxes of freshwater on the ecology of the current system $[62,63]$, including the effects on important commercial and recreational species, such as spotted seatrout Cynoscion nebulosus, red drum Sciaenops ocellatus, Gulf menhaden Brevoortia patronus, blue crab Callinectes sapidus, and penaid shrimp. These effects vary with discharge and are often localized [64]. Modeling has also been used as a tool in such evaluations. For example, the simulations of fish response to the operation of the Caernarvon freshwater diversion showed movement down the estuary of Bay Anchovy Anchoa mitchilli, which agrees with field observations [63]. The long-term simulations of fish communities in Barataria, Breton, and Pontchartrain basins in response to the 
sea-level rise and the inflow from four large river diversions (Mid-Barataria, Mid-Breton, Lower Breton in Table 1 and an additional diversion into Lower Barataria) showed local shifts in the distribution of six species of ecological and economic importance including the Eastern oyster Crassostrea virginica [65]. Some changes were the direct effects of decreased salinity while other effects were related to reduced $\mathrm{Chl} a$ due to increased turbidity, a trend also identified in the field and literature-based studies [66]. The simulations also showed that local biomass reductions were mostly the result of redistribution, as there was minimal impact on the total biomass compared to a future without action.

The ecological effect of the larger scale riverine inflow is likely complex. An examination of the salinity sensitivity of 44 estuarine fish species, including many of economic importance, in the Gulf of Mexico estuaries found many species showing low or moderate sensitivity to the salinity change [67]. However, freshwater fishes currently in the extensive areas of the basin $>0.6 \mathrm{ppt}$, may be impacted by increased salinity through the impacts on physiological costs (e.g., osmoregulation) which may be offset through increased productivity and greater food availability [68]. Further, experimental studies using coastal marsh fish which are found across the salinity gradient showed that descendants of individuals from brackish populations had better survival when exposed to salinity than fish with no historical exposure to salinity, suggesting genetic adaptation [69].

\subsection{Lessons for Future Management}

It is not a new concept that large-scale river diversions into the Mississippi River estuary could utilize an operational regime which mimics the natural fluctuations of riverine flood events [70]. Crevasses and small uncontrolled diversions show such a flow regime [71,72] in contrast to the near continuous flow of a delta distributary channel. This analysis examined three distinct operational regimes to explore how a diversion could be operated to mimic a seasonal high flow and sediment pulse that is typically seen in the springtime Mississippi River flows [10,45,70]. Capturing an equivalent amount of diverted water, the flood-wave specific operations are able to capture and deliver a greater load of sediment from the river and distribute it to the estuary (Figure 12). This regime has the largest impact during river years with below-average flowrates when the total annual load must be scheduled during shorter periods (Figure S1 in Supplementary Material). This operation regime, while simple enough to implement in a model with assigned boundary conditions, the real-world implementation would be challenging, given the inability for accurate seasonal forecasts of the flow in the Mississippi River. In practice, such a regime would likely operate as soon as the river is high enough (typically in the spring) and continue until the annual sediment/freshwater load mass/volume were met.

An additional benefit from flood-mimicking operational regimes is that the concentrations of suspended sediments within the Mississippi River waters (both fines and sands) vary in relation to flood events and annual cycles [73]. The current flow-to-sediment rating curves for the lowermost Mississippi River show a hysteresis effect where the rising limb of the annual river flood has a flushing effect and carries a greater suspended sediment load than an equivalent flowrate on the falling limb of the flood hydrograph [10]. The scheduling diversion operations for the arrival of the floodwave allow for the most efficient delivery of suspended sediments from the Mississippi River into the estuary (Figure 12).

The simulations presented in this report provided insights on how the system responds to a variety of operation plans. Some of the responses are not intuitive, emphasizing the value of using such holistic landscape models that capture (to the extent possible) feedbacks and interactions among various processes. The FWOA simulation shows a dramatic change in salinity in parts of the system due to the sea-level rise. The rate of the eustatic sea-level rise accelerates over time in the simulation and is assumed to be the lead cause of that significant increase in salinities in the last decade. These changes have been shown to have dramatic effects on vegetation [32] and, in combination with the changes in temperature, can dramatically influence the distribution of aquatic species [34].

One important aspect of using the resources of the Mississippi River to manage the coastal ecosystem in the face of the sea-level rise is that it allows the management of conditions to achieve 
a variety of goals, e.g., land building or positioning suitable salinity conditions for fishery benefits, as well as the ability to adjust to changing conditions. The simulations here all apply a fixed set of rules over time. In reality, the diversions are likely to be managed in response to estuarine (and river) conditions. The effects of the drought event in the last decade of the simulation were in some way ameliorated by the various diversion configurations (Figures 5-7) even with operational rules which were not designed to specifically address such situations. As the implementation of diversions proceeds, near-term forecasting models of estuarine conditions and adaptable operational rules for diversion flows may be useful to further protect against massive interannual fluctuations on estuarine conditions. However, this study has shown that planning how many diversions are needed and at which locations within the estuary must focus on the long-term in order that the effects of the sea-level rise can be integrated into decision making.

\section{Conclusions}

The simulations described here show, for the estuarine basins of the Mississippi Delta Plain, that the effects of the sea-level rise decades into the future are potentially dramatic, but the effects on the estuarine salinity gradient varies according to the landscape setting. The analysis demonstrates that the ecological character of the future system is dependent on both the sea-level rise and the management of river resources. The pronounced incursion of higher salinity water into Barataria in later years of the simulation associated with the relative sea-level rise was largely offset by the freshwater inputs from the planned Mid-Barataria diversion. While sediment delivery is frequently the focus of future river diversions in the Mississippi River Delta, this analysis has shown how large-scale river diversions also affect spatiotemporal patterns in the salinity gradient throughout the estuarine basins, combatting the effects of a future sea-level rise by maintaining present-day salinity variations throughout the basin. The spatial extent of these salinity gradients varies annually due to the variability in riverine freshwater flows reaching the delta and are also susceptible to the number (and operational regime) of engineered diversions and natural distributary channels into the estuary.

Supplementary Materials: The following are available online at http://www.mdpi.com/2073-4441/11/10/2028/s1: ICM Overview and ICM Simulation Settings. Please contact the corresponding author for access to model source code repositories on GitHub.

Author Contributions: The co-authors contributed to the research and preparation of this manuscript in the following ways: conceptualization, E.M., D.R., N.P.S., A.R., and E.D.W.; methodology, E.D.W., Y.W., E.M., and D.R.; software, E.D.W., Y.W., E.M., and others listed in acknowledgements; investigation, E.D.W., Y.W., D.R., and E.M.; writing - original draft preparation, E.D.W., Y.W., D.R., E.M. and A.R.; writing-review and editing, D.R., A.R., E.D.W., N.P.S. and E.M.; visualization, E.D.W., Y.W. and A.R.; supervision, D.R., E.M., A.R. and N.P.S.; project administration, N.P.S. and A.R.; funding acquisition, N.P.S.

Funding: This analysis was funded by Environmental Defense Fund (EDF) (grant number 1048-000005-10650; \#7557790/\#7930492) through support from the Gilder Foundation.

Acknowledgments: The Integrated Compartment Model development and calibration discussed in this work was initially funded by the Louisiana Coastal Protection and Restoration Authority; the authors are indebted to the many researchers and engineers who participated in the 2017 Coastal Master Plan analyses and assisted in those efforts. We would like to acknowledge fellow model developers for the various subroutines of the ICM including (among many others): Alex McCorquodale, Jenneke Visser, Scott Duke-Sylvester, Brady Couvillion and Zhifei Dong.

Conflicts of Interest: The authors declare no conflicts of interest.

\section{References}

1. Nicholls, R.J.; Wong, P.P.; Burkett, V.; Codignotto, J.; Hay, J.; McLean, R.; Ragoonaden, S.; Woodroffe, C.D.; Abuodha, P.A.O.; Arblaster, J.; et al. Coastal systems and low-lying areas. In Climate Change 2007: Impacts, Adaptation and Vulnerability; Parry, M.L., Canziani, O.F., Palutikof, J.P., van der Linden, P.J., Hanson, C.E., Eds.; Contribution of Working Group II to the Fourth Assessment Report of the Intergovernmental Panel on Climate Change; Cambridge University Press: Cambridge, UK, 2007; pp. 315-356. 
2. Wong, P.P.; Losada, I.J.; Gattuso, J.-P.; Hinkel, J.; Khattabi, A.; McInnes, K.L.; Saito, Y.; Sallenger, A. Coastal Systems and Low-Lying Areas. In Climate Change 2014: Impacts, Adaptation, and Vulnerability; Part A: Global and Sectoral Aspects. Contribution of Working Group II to the Fifth Assessment Report of the Intergovernmental Panel on Climate Change; Cambridge University Press: Cambridge, UK, 2014; p. 49.

3. Syvitski, J.P.M.; Kettner, A.J.; Overeem, I.; Hutton, E.W.H.; Hannon, M.T.; Brakenridge, G.R.; Day, J.; Vörösmarty, C.; Saito, Y.; Giosan, L.; et al. Sinking deltas due to human activities. Nat. Geosci. 2009, 2, 681-686. [CrossRef]

4. Coleman, J.M.; Roberts, H.H.; Stone, G.W. Coleman. Mississippi River Delta: An Overview. J. Coast. Res. 1998, 14, 689-716.

5. Couvillion, B.R.; Beck, H.; Schoolmaster, D.; Fischer, M. Land Area Change in Coastal Louisiana (1932 to 2016); USGS Numbered Series 3381; Geological Survey: Reston, VA, USA, 2017. Available online: http://pubs.er.usgs.gov/publication/sim3381 (accessed on 11 December 2018).

6. Yuill, B.; Lavoie, D.; Reed, D.J. Understanding Subsidence Processes in Coastal Louisiana. J. Coast. Res. 2009, 23-36. [CrossRef]

7. Boesch, D.F.; Josselyn, M.N.; Mehta, A.J.; Morris, J.T.; Nuttle, W.K.; Simenstad, C.A.; Swift, D.J.P. Scientific Assessment of Coastal Wetland Loss, Restoration and Management in Louisiana. J. Coast. Res. 1994, 10, $1-103$.

8. Barry, J.M. Rising Tide: The Great Mississippi Flood of 1927 and How It Changed America; Simon and Schuster: New York, NY, USA, 2007.

9. Corthell, E. The delta of the Mississippi River. Natl. Geogr. 1897, 12, 351-354.

10. Allison, M.A.; Demas, C.R.; Ebersole, B.A.; Kleiss, B.A.; Little, C.D.; Meselhe, E.A.; Powell, N.J.; Pratt, T.C.; Vosburg, B.M. A water and sediment budget for the lower Mississippi-Atchafalaya River in flood years 2008-2010: Implications for sediment discharge to the oceans and coastal restoration in Louisiana. J. Hydrol. 2012, 432, 84-97. [CrossRef]

11. Nittrouer, J.A.; Best, J.L.; Brantley, C.; Cash, R.W.; Czapiga, M.; Kumar, P.; Parker, G. Mitigating land loss in coastal Louisiana by controlled diversion of Mississippi River sand. Nat. Geosci. 2012, 5, 534-537. [CrossRef]

12. Kim, W.; Mohrig, D.; Twilley, R.; Paola, C.; Parker, G. Is It Feasible to Build New Land in the Mississippi River Delta? EOS 2009, 90, 373-374. [CrossRef]

13. Paola, C.; Twilley, R.R.; Edmonds, D.A.; Kim, W.; Mohrig, D.; Parker, G.; Viparelli, E.; Voller, V.R. Natural Processes in Delta Restoration: Application to the Mississippi Delta. Annu. Rev. Mar. Sci. 2011, 3, 67-91. [CrossRef]

14. Elsey-Quirk, T.; Graham, S.; Mendelssohn, I.; Snedden, G.; Day, J.; Twilley, R.; Shaffer, G.; Sharp, L.; Pahl, J.; Lane, R. Mississippi river sediment diversions and coastal wetland sustainability: Synthesis of responses to freshwater, sediment, and nutrient inputs. Estuar. Coast. Shelf Sci. 2019, 221, 170-183. [CrossRef]

15. Reed, D.J. Planning for the Future of the Pontchartrain Coast. J. Coast. Res. 2009, SI54, 198-205. [CrossRef]

16. Soniat, T.M.; Conzelmann, C.P.; Byrd, J.D.; Roszell, D.P.; Bridevaux, J.L.; Suir, K.J.; Colley, S.B. Predicting the Effects of Proposed Mississippi River Diversions on Oyster Habitat Quality; Application of an Oyster Habitat Suitability Index Model. J. Shellfish. Res. 2013, 32, 629-638. [CrossRef]

17. Adamack, A.; Stow, C.; Mason, D.; Rozas, L.; Minello, T. Predicting the effects of freshwater diversions on juvenile brown shrimp growth and production: A Bayesian-based approach. Mar. Ecol. Prog. Ser. 2012, 444, 155-173. [CrossRef]

18. Rozas, L.P.; Minello, T.J. Variation in penaeid shrimp growth rates along an estuarine salinity gradient: Implications for managing river diversions. J. Exp. Mar. Biol. Ecol. 2011, 397, 196-207. [CrossRef]

19. De Mutsert, K.; Cowan, J.H. A Before-After-Control-Impact Analysis of the Effects of a Mississippi River Freshwater Diversion on Estuarine Nekton in Louisiana, USA. Chesap. Sci. 2012, 35, 1237-1248. [CrossRef]

20. Coastal Protection and Restoration Authority of Louisiana. Integrated Ecosystem Restoration and Protection: Louisiana's Comprehensive Master Plan for a Sustainable Coast; Coastal Protection and Restoration Authority of Louisiana: Baton Rouge, LA, USA, 2007.

21. Coastal Protection and Restoration Authority of Louisiana. Louisiana's Comprehensive Master Plan for a Sustainable Coast-2012; Coastal Protection and Restoration Authority of Louisiana: Baton Rouge, LA, USA, 2012. 
22. Coastal Protection and Restoration Authority of Louisiana. Lousiana's Comprehensive Master Plan for a Sustainable Coast-2017; Coastal Protection and Restoration Authority of Louisiana: Baton Rouge, LA, USA, 2017.

23. White, E.D.; Meselhe, E.; McCorquodale, A.; Couvillion, B.; Dong, Z.; Duke-Sylvester, S.M.; Wang, Y. 2017 Coastal Master Plan: Attachment C3-22: Integrated Compartment Model (ICM) Development; Coastal Protection and Restoration Authority: Baton Rouge, LA, USA, 2017.

24. Meselhe, E.; McCorquodale, J.A.; Shelden, J.; Dortch, M.S.; Brown, T.S.; Elkan, P.; Rodrigue, M.D.; Schindler, J.K.; Wang, Z. Ecohydrology Component of Louisiana's 2012 Coastal Master Plan: Mass-Balance Compartment Model. J. Coast. Res. 2013, 67, 16-28. [CrossRef]

25. Visser, J.M.; Duke-Sylvester, S.M. LaVegMod v2: Modeling Coastal Vegetation Dynamics in Response to Proposed Coastal Restoration and Protection Projects in Louisiana, USA. Sustainability 2017, 9, 1625. [CrossRef]

26. Couvillion, B.R.; Steyer, G.D.; Wang, H.; Beck, H.J.; Rybczyk, J.M. Forecasting the Effects of Coastal Protection and Restoration Projects on Wetland Morphology in Coastal Louisiana under Multiple Environmental Uncertainty Scenarios. J. Coast. Res. 2013, 67, 29-50. [CrossRef]

27. Folse, T.M.; Sharp, L.A.; West, J.L.; Hymel, M.K.; Troutman, J.P.; McGinnis, T.; Weifenbach, D.; Boshart, W.M.; Rodrigue, L.B.; Richardi, D.C.; et al. A Standard Operating Procedures Manual for the Coast-wide Reference Monitoring System-Wetlands: Methods for Site Establishment, Data Collection, and Quality Assurance/Quality Control; Louisiana Coastal Protection and Restoration Authority, Office of Coastal Protection and Restoration: Baton Rouge, LA, USA, 2018; p. 228.

28. Couvillion, B. 2017 Coastal Master Plan Modeling: Attachment C3-27: Landscape Data; Coastal Protection and Restoration Authority: Baton Rouge, LA, USA, 2017.

29. Patankar, S. Numerical Heat Transfer and Fluid Flow; CRC Press: Boca Raton, FL, USA, 1980; p. 214.

30. White, E.D.; Messina, F.; Moss, L.; Meselhe, E. Salinity and Marine Mammal Dynamics in Barataria Basin: Historic Patterns and Modeled Diversion Scenarios. Water 2018, 10, 1015. [CrossRef]

31. White, E.D.; Reed, D.J.; Meselhe, E.A. Modeled Sediment Availability, Deposition, and Decadal Land Change in Coastal Louisiana Marshes under Future Relative Sea Level Rise Scenarios. Wetlands 2019. [CrossRef]

32. Baustian, M.M.; Clark, F.R.; Jerabek, A.S.; Wang, Y.; Bienn, H.C.; White, E.D. Modeling current and future freshwater inflow needs of a subtropical estuary to manage and maintain forested wetland ecological conditions. Ecol. Indic. 2018, 85, 791-807. [CrossRef]

33. Reed, D.; Meselhe, E.; White, E.; Wang, Y. Wetland transitions and loss in coastal Louisiana under scenarios of future relative sea-level rise. Geomorphology 2019. under review.

34. Hijuelos, A.C.; Sable, S.E.; O'Connell, A.M.; Geaghan, J.P.; Lindquist, D.C.; White, E.D. Application of Species Distribution Models to Identify Estuarine Hot Spots for Juvenile Nekton. Estuaries Coasts 2017, 40, 1183-1194. [CrossRef]

35. Meselhe, E.; White, E.D.; Reed, D.J. 2017 Coastal Master Plan: Appendix C: Modeling Chapter 2-Future Scenarios; Coastal Protection and Restoration Authority: Baton Rouge, LA, USA, 2017.

36. Brown, S.; Couvillion, B.; Dong, Z.; Meselhe, E.; Visser, J.; Wang, Y.; White, E. 2017 Coastal Master Plan: Attachment C3-23: ICM Calibration, Validation, and Performance Assessment; Coastal Protection and Restoration Authority: Baton Rouge, LA, USA, 2017.

37. McCorquodale, A.; Couvillion, B.; Dortch, M.S.; Freeman, A.; Meselhe, E.; Reed, D.; Roth, B.; Shelden, J.; Wang, H.; White, E. 2017 Coastal Master Plan: Appendix C: Attachment C3-1: Sediment Distribution; Coastal Protection and Restoration Authority: Baton Rouge, LA, USA, 2017.

38. Allison, M.A.; Chen, Q.J.; Couvillion, B.; Leadon, M.; McCorquodale, A.; Meselhe, E.; Ramatchandirane, C.; Reed, D.J.; White, E.D. 2017 Coastal Master Plan: Model Improvement Plan, Attachment C3-2: Marsh Edge Erosion; Coastal Protection and Restoration Authority: Baton Rouge, LA, USA, 2017.

39. Pahl, J. 2017 Coastal Master Plan: Attachment C-2: Eustatic Sea Level Rise; Coastal Protection and Restoration Authority: Baton Rouge, LA, USA, 2017.

40. Brown, S. 2017 Coastal Master Plan Modeling: Attachment C3-26: Hydrology and Water Quality Boundary Conditions; Version Final; Coastal Protection and Restoration Authority: Baton Rouge, LA, USA, 2017.

41. Meselhe, E.; White, E.; Wang, Y. 2017 Coastal Master Plan: Attachment C3-24: Integrated Compartment Model Uncertainty Analysis; Coastal Protection and Restoration Authority: Baton Rouge, LA, USA, 2017. 
42. Reed, D.; Yuill, B. 2017 Coastal Master Plan: Attachment C2-2: Subsidence; Coastal Protection and Restoration Authority: Baton Rouge, LA, USA, 2017.

43. Allison, M.A.; Meselhe, E.A. The use of large water and sediment diversions in the lower Mississippi River (Louisiana) for coastal restoration. J. Hydrol. 2010, 387, 346-360. [CrossRef]

44. Baustian, M.M.; Meselhe, E.; Jung, H.; Sadid, K.; Duke-Sylvester, S.M.; Visser, J.M.; Allison, M.A.; Moss, L.C.; Ramatchandirane, C.; Van Maren, D.S.; et al. Development of an Integrated Biophysical Model to represent morphological and ecological processes in a changing deltaic and coastal ecosystem. Environ. Model. Softw. 2018, 109, 402-419. [CrossRef]

45. Xu, K.; Bentley, S.J.; Day, J.W.; Freeman, A.M. A review of sediment diversion in the Mississippi River Deltaic Plain. Estuar. Coast. Shelf Sci. 2019, 225, 106241. [CrossRef]

46. Gaweesh, A.; Meselhe, E. Evaluation of Sediment Diversion Design Attributes and Their Impact on the Capture Efficiency. J. Hydraul. Eng. 2016, 142, 04016002. [CrossRef]

47. Allison, M.A.; Ramirez, M.T.; Meselhe, E.A. Diversion of Mississippi River Water Downstream of New Orleans, Louisiana, USA to Maximize Sediment Capture and Ameliorate Coastal Land Loss. Water Resour. Manag. 2014, 28, 4113-4126. [CrossRef]

48. McKee, K.L.; Cahoon, D.R.; Feller, I.C. Caribbean mangroves adjust to rising sea level through biotic controls on change in soil elevation. Glob. Ecol. Biogeogr. 2007, 16, 545-556. [CrossRef]

49. Morris, J.T.; Sundareshwar, P.V.; Nietch, C.T.; Kjerfve, B.; Cahoon, D.R. Responses of coastal wetlands to rising sea level. Ecology 2002, 83, 2869-2877. [CrossRef]

50. Craft, C.; Clough, J.; Ehman, J.; Joye, S.; Park, R.; Pennings, S.; Guo, H.; Machmuller, M. Forecasting the effects of accelerated sea-level rise on tidal marsh ecosystem services. Front. Ecol. Environ. 2009, 7, 73-78. [CrossRef]

51. Reyes, E.; Georgiou, I.; Reed, D.; McCorquodale, A. Using Models to Evaluate the Effects of Barrier Islands on Estuarine Hydrodynamics and Habitats: A Numerical Experiment. J. Coast. Res. 2005, SI44, 176-185.

52. Munoz, S.E.; Giosan, L.; Therrell, M.D.; Remo, J.W.F.; Shen, Z.; Sullivan, R.M.; Wiman, C.; O’Donnell, M.; Donnelly, J.P. Climatic control of Mississippi River flood hazard amplified by river engineering. Nature 2018, 556, 95-98. [CrossRef] [PubMed]

53. Krysanova, V.; Vetter, T.; Eisner, S.; Huang, S.; Pechlivanidis, I.; Strauch, M.; Gelfan, A.; Kumar, R.; Aich, V.; Arheimer, B.; et al. Intercomparison of regional-scale hydrological models and climate change impacts projected for 12 large river basins worldwide-A synthesis. Environ. Res. Lett. 2017, 12, 105002. [CrossRef]

54. La Peyre, M.K.; Geaghan, J.; Decossas, G.; La Peyre, J.F.; Peyre, L. Analysis of Environmental Factors Influencing Salinity Patterns, Oyster Growth, and Mortality in Lower Breton Sound Estuary, Louisiana, Using 20 Years of Data. J. Coast. Res. 2016, 319, 519-530. [CrossRef]

55. Lellis-Dibble, K.A.; McGlynn, K.E.; Bigford, T.E. Estuarine Fish and Shellfish Species in U.S. Commercial and Recreational Fisheries: Economic Value as an Incentive to Protect and Restore Estuarine Habitat; NOAA Tech, Memo, NMFSF/SPO-90; U.S. Dep Commerce.: Silver Spring, MD, USA, 2008; pp. 1-94.

56. Chen, W.; Chen, K.; Kuang, C.; Zhu, D.Z.; He, L.; Mao, X.; Liang, H.; Song, H. Influence of sea level rise on saline water intrusion in the Yangtze River Estuary, China. Appl. Ocean Res. 2016, 54, 12-25. [CrossRef]

57. Cloern, J.E.; Abreu, P.C.; Carstensen, J.; Chauvaud, L.; Elmgren, R.; Grall, J.; Greening, H.S.; Johansson, J.O.R.; Kahru, M.; Sherwood, E.T.; et al. Human activities and climate variability drive fast-paced change across the world's estuarine-coastal ecosystems. Glob. Chang. Biol. 2016, 22, 513-529. [CrossRef]

58. Yang, Z.; Wang, T.; Voisin, N.; Copping, A. Estuarine response to river flow and sea-level rise under future climate change and human development. Estuar. Coast. Shelf Sci. 2015, 156, 19-30. [CrossRef]

59. Cloern, J.E.; Kimmerer, W.; Moyle, P.B.; Mueller-Solger, A.; Moyle, P.B.; Kay, J. Water Wasted to the Sea? SFEWS 2017, 15. [CrossRef]

60. Montagna, P.A.; Alber, M.; Doering, P.; Connor, M.S. Freshwater inflow: Science, policy, management. Estuaries 2002, 25, 1243-1245. [CrossRef]

61. Peyronnin, N.S.; Caffey, R.H.; Cowan, J.H.; Justic, D.; Kolker, A.S.; Laska, S.B.; McCorquodale, A.; Melancon, E.; Nyman, J.A.; Twilley, R.R.; et al. Optimizing Sediment Diversion Operations: Working Group Recommendations for Integrating Complex Ecological and Social Landscape Interactions. Water 2017, 9, 368. [CrossRef]

62. Mutsert, K.D.; Cowan, J.H., Jr.; Walters, C.J. Using Ecopath with Ecosim to Explore Nekton Community Response to Freshwater Diversion into a Louisiana Estuary. Mar. Coast. Fish. 2012, 4, 104-116. [CrossRef] 
63. Rose, K.A.; Huang, H.; Justic, D.; De Mutsert, K. Simulating Fish Movement Responses to and Potential Salinity Stress from Large-Scale River Diversions. Mar. Coast. Fish. 2014, 6, 43-61. [CrossRef]

64. Piazza, B.P.; La Peyre, M.K. Nekton community response to a large-scale Mississippi River discharge: Examining spatial and temporal response to river management. Estuar. Coast. Shelf Sci. 2011, 91, 379-387. [CrossRef]

65. De Mutsert, K.; Lewis, K.; Milroy, S.; Buszowski, J.; Steenbeek, J. Using ecosystem modeling to evaluate trade-offs in coastal management: Effects of large-scale river diversions on fish and fisheries. Ecol. Model. 2017, 360, 14-26. [CrossRef]

66. Bargu, S.; Justic, D.; White, J.R.; Lane, R.; Day, J.; Paerl, H.; Raynie, R. Mississippi River diversions and phytoplankton dynamics in deltaic Gulf of Mexico estuaries: A review. Estuar. Coast. Shelf Sci. 2019, 221, 39-52. [CrossRef]

67. Christensen, J.D.; Monaco, M.E.; Lowery, T.A. An Index to Assess the Sensitivity of Gulf of Mexico Species to Changes in Estuarine Salinity Regimes. Gulf Res. Rep. 1997, 9, 219-229. [CrossRef]

68. Peterson, M.S.; Meador, M.R. Effects of salinity on freshwater fishes in coastal plain drainages in the southeastern U.S. Rev. Fish. Sci. 1994, 2, 95-121. [CrossRef]

69. Purcell, K.M.; Hitch, A.T.; Klerks, P.L.; Leberg, P.L. Adaptation as a potential response to sea-level rise: A genetic basis for salinity tolerance in populations of a coastal marsh fish. Evol. Appl. 2008, 1, 155-160. [CrossRef]

70. Day, J.W.; Lane, R.R.; D’Elia, C.F.; Wiegman, A.R.; Rutherford, J.S.; Shaffer, G.P.; Brantley, C.G.; Kemp, G.P.; D'Elia, C.F. Large infrequently operated river diversions for Mississippi delta restoration. Estuar. Coast. Shelf Sci. 2016, 183, 292-303. [CrossRef]

71. Yuill, B.T.; Khadka, A.K.; Pereira, J.; Allison, M.A.; Meselhe, E.A. Morphodynamics of the erosional phase of crevasse-splay evolution and implications for river sediment diversion function. Geomorphology 2016, 259, 12-29. [CrossRef]

72. Cahoon, D.R.; White, D.A.; Lynch, J.C. Sediment infilling and wetland formation dynamics in an active crevasse splay of the Mississippi River delta. Geomorphology 2011, 131, 57-68. [CrossRef]

73. Mossa, J. Sediment dynamics in the lowermost Mississippi River. Eng. Geol. 1996, 45, 457-479. [CrossRef]

(C) 2019 by the authors. Licensee MDPI, Basel, Switzerland. This article is an open access article distributed under the terms and conditions of the Creative Commons Attribution (CC BY) license (http://creativecommons.org/licenses/by/4.0/). 